MACIEJ ZĄBEK

Uniwersytet Warszawski

\title{
Spowiedź antropologiczna. \\ Z notatek PRL-owskiego etnografa - o niektórych kontekstach badań terenowych w Sudanie
}

\section{Dlaczego etnografia?}

Dowody, dla których ktoś zaczął studiować etnografię, etnologię i antropologię 1 mogą być oczywiście, w przypadku różnych osób, różne. Dla mnie i - jak sądzę - nie tylko, głównym powodem, aby zostać etnografem, była ta szczególna magia terenu, podróży do miejsc odległych i nieznanych, spotkania z innymi, szansa uczestniczenia w ich w realnym życiu, w zupełnie obcym środowisku, poza biblioteką i akademią. Nadzieja "wielkiej przygody" i nuta ekscentryzmu, która towarzyszyła od początku naszej trójimiennej dyscyplinie.

W każdym razie, będąc jeszcze nastolatkiem, nie tyle interesowałem się „,kulturą" a tym bardziej „kulturą ludową”, co raczej geografią, marząc o dalekich podróżach, poznawaniu innych światów i po prostu pragnąc zanurzenia się w "obcość". Była w tym pewna doza ojkofobii, niechęci do otaczającego mnie prowincjonalnego, szarego, kołtuńskiego, ksenofobicznego środowiska, szkół do których chodziłem i ówczesnej zakłamanej rzeczywistości politycznej PRL-u, w której żyłem. Uczuciom tym towarzyszyła nieprzeparta chęć ucieczki, za wszelką cenę. Nie było to wprawdzie niczym niezwykłym w moim pokoleniu, w którym co najmniej połowa marzyła o „ucieczce" na Zachód, tyle że w moim przypadku było to marzenie o ucieczce raczej do Indian znad Amazonki lub Papuasów na Nowej Gwinei. 
Sam termin kultura, w zasadzie do dziś, został dla mnie tylko narzędziem umożliwiającym, w świecie nauki podzielonym na dyscypliny, nieograniczanie zainteresowań do jednej tylko dziedziny, drogą pozwalającą na interdyscyplinarność, holistyczność i przekraczanie różnych granic, a przede wszystkim na wyjście poza własny świat (zob. Pobłocki 2018). Nie podzielam także krytyki Adama Kupera sugerującej, że termin „kultura” jest tylko eufemizmem pojęcia „rasy”, wywierającym nadmierny wpływ na działania jednostek (Kuper 1999).

„Etnografia” kojarzyła mi się początkowo tylko ze skansenami i „Cepelią”, a więc niczym szczególnie porywającym. Pozostałych „imion” naszej dyscypliny jeszcze nie znałem, dopiero po przeczytaniu Księgi Indian (Lips 1971) i Indian z Meksyku (Benitez 1972), zacząłem odkrywać dla siebie to szczególne połączenie etnografii, etnologii i antropologii. Odtąd etnografia (od początku w rozumieniu prowadzenia badań terenowych) była już moim jedynym celem, słodką tajemnicą, o której nie mogłem nikomu powiedzieć, bo nikt z mego otoczenia nie zrozumiałby tego. Celem, który po zaliczeniu jeszcze kilku porażek życiowych i rozczarowań, osiągnąłem dopiero po wielu latach.

\section{Wyprawy do Afryki}

Dostanie się na studia, na ówczesną „etnografię” na Uniwersytecie Warszawskim, było dopiero pierwszym etapem na tej drodze. Był rok 1980, czas Solidarności, realizacja moich planów życiowych wydawała się zupełnie niemożliwa. Jednak marzenia, abym, jak Malinowski, wreszcie stanął „sam na tropikalnej plaży w pobliżu wioski tubylców” (Malinowski 1981a: 31), nie pozwalały o nich zapomnieć. Wstępem do ich realizacji było już na pewno „laboratorium cyganologiczne" prowadzone przez ówczesnego doktora (dziś już profesora emerytowanego) Lecha Mroza i badania w ramach jego własnego projektu. Zdecydowałem się na dłuższy pobyt, sam na sam z Cyganami, w osadzie tzw. Romów karpackich w Szaflarach, w lipcu 1983 r. Było to już coś innego niż chodzenie na wywiady w ramach ćwiczeń terenowych. Nie wytrzymałem w tej osadzie jednak dłużej niż miesiąc. Powinienem to pierwsze doświadczenie "zanurzenia się w obcości" potraktować jako ostrzeżenie, że bez dobrego pomysłu i teorii niewiele się "odkryje”, a "tubylcy”, jacy by nie byli, tak naprawdę nigdy nie są tak „romantyczni” i „egzotyczni”, jakimi wydają się być w niektórych książkach.

W ponurym czasie ostatniej dekady tzw. "realnego socjalizmu” pojawiła się w naszym studenckim środowisku idea organizowania ekspedycji etnograficznych na inne kontynenty. Koledzy postanowili zorganizować wyprawę do Indii. Podjąłem się wówczas organizacji konkurencyjnej wyprawy do Afryki „szlakiem Jana Czekanowskiego”, do której namówiłem kilka osób ze studiów i Jacka Łapotta ${ }^{1}$ z Muzeum Narodowego w Szczecinie, mającego już doświadczenie $\mathrm{z}$ takiej wyprawy. O kontynencie tym niewiele wiedziałem, sądząc naiwnie,

\footnotetext{
${ }^{1}$ Obecnie prof. uczelni na Uniwersytecie Szczecińskim.
} 
że podróż do Afryki będzie logistycznie nawet łatwiejsza niż do Indii (pamiętać trzeba, że internetu wówczas nie było, a znalezienie osób, które miałyby aktualne informacje też nie było możliwe). Szybko przekonałem się, jak bardzo się pomyliłem! Niemniej przygotowania do wyprawy nauczyły mnie „załatwiania” spraw "nie do załatwienia", czy to u Rektora, czy w jednym lub drugim Ministerstwie. Przygotowania wymagały umiejętności pozyskiwania pomocy w państwowych przedsiębiorstwach i w rozwijających się wówczas tzw. firmach "polonijnych", a także „kolaborowania” ze Zrzeszeniem Studentów Polskich (ZSP), bez pośrednictwa którego nie było możliwe nawet otrzymanie paszportów, nie mówiąc już o przydziale pewnej drobnej kwoty waluty wymienialnej. Niezbędne było w końcu dokonanie zakupu starej ciężarówki z tzw. rezerw nienaruszalnych z jednostki wojskowej w Toruniu. Ciężarówki, jak powtarzała szefowa naszej Katedry, prof. Zofia Sokolewicz, były podstawowym sprzętem do prowadzenia badań w Afryce, gdyż - jak jej kiedyś powiedzieli znajomi Anglicy - „najpierw trzeba kupić sobie lorry" (zob. Sokolewicz 2017).

Wielomiesięczne wyprawy, w których uczestniczyliśmy - pierwsza od listopada 1984 r. do czerwca 1985 r., druga od grudnia 1986 r. do maja 1987 r. - przynajmniej z perspektywy deklarowanych celów nie były sukcesem, choć kilku uczestników uratowało "honor" i zebrało materiały wystarczające do napisania prac magisterskich, nie mówiąc już o pozyskanej pokaźnej liczbie eksponatów dla muzeów polskich. W trakcie tej podróży przeżyliśmy niejedną niespodziankę. Nigdy nie zapomnę, jak nasz samochód typu „Star 66" zepsuł się zaraz po wyruszeniu w drogę i trzeba było go błyskawicznie reperować w Jednostce Nadwiślańskiej MSW jeszcze w Warszawie. O mało co nie spóźniliśmy się z załadowaniem go na statek w Gdańsku, skąd miał odpłynąć do portu w Aleksandrii. Gdy już tam dotarł, przez dwa tygodnie nie można go było wydostać z portu, a później musieliśmy przez kolejne trzy miesiące czekać w Egipcie na wizy sudańskie - co dwa tygodnie kupować dolary i sprzedawać lokalną walutę, aby dostać kolejną wizę. Wszystkie te operacje i sam pobyt w Egipcie ostatecznie spowodowały, że nasze skromne środki stopniały szybko i w końcu musieliśmy przemycać brandy do Sudanu, gdzie obowiązywało islamskie prawo karne, aby mieć jakieś pieniądze, które i tak nam w Chartumie ukradziono. Wyprawa skończyła się w Górach Nuba, a na ",szlak Czekanowskiego" w Kongo nigdy już nie dotarliśmy. Niemniej po wyprawie zostało mi wspomnienie pierwszego zwodniczego zauroczenia Afryką, pierwszych doświadczeń z kontaktów z Afrykanami i poczucie, że $\mathrm{w}$ pewnym stopniu spełniło się moje marzenie o znalezieniu się $\mathrm{w}$ zupełnie innym świecie. Nic dziwnego, że z chwilą powrotu do kraju zaczęliśmy przygotowania do kolejnego wyjazdu, do którego doszło w grudniu 1986 r.

Tym razem postanowiliśmy ominąć Egipt i dotrzeć do Sudanu drogą lądową przez Afrykę Zachodnią. Niestety, zamiast dokończyć rozpoczęte badania w Górach Nuba, jak było to wcześniej planowane, z uwagi na wojnę w Czadzie

${ }^{2}$ Dziś w ten sposób byłyby one tym bardziej nie do "załatwienia".Przeciętny student o dostępie do Rektora czy swobodnym wejściu do Ministerstwa Finansów może tylko pomarzyć. 
i zamieszki w Darfurze ekspedycja skierowała się ostatecznie w zupełnie inną stronę kontynentu. W czasie jej trwania o mało nie utopiliśmy naszej ciężarówki na atlantyckiej plaży podczas przy pływu, a potem nie zostawiliśmy jej z pękniętą głowicą silnika na środku Sahary, w drodze do Agades w Nigrze. Trzeba było sprowadzić drogą lotniczą nową głowicę, i to z Sudanu, gdzie były takie samochody, a w konsulacie czekały na nas pieniądze pozyskane $\mathrm{w}$ drodze bezpośredniej wymiany naszych niewymienialnych złotych na równie niewymienialne funty sudańskie (mieliśmy w końcu jechać do Sudanu). Niemniej dotarliśmy do dwóch miejsc badawczych u ludów Somba w Beninie i Lobi w Burkina Faso, a ja nawet napisałem na podstawie tych materiałów pracę magisterską. W drodze powrotnej „zaliczyłem" też pierwszą malarię. Przygód mieliśmy wiele, jednak nie odczułem doświadczenia Malinowskiego, które było moim osobistym celem, a do realizacji badań w trybie ekspedycyjnym, metodą Czekanowskiego, także było nam daleko. Rozczarowanie spowodowało, że miałem na jakiś czas dosyć wypraw grupowych. Nabrałem natomiast przeświadczenia, że w Afryce poradzę sobie już sam.

\section{Przygotowania do wyjazdu}

W jaki jednak sposób można było wyjechać na badania do Afryki w czasach, gdy nie było możliwości pozyskania żadnych grantów, a stypendia na wymianę naukową z państwami Afryki były już w tym czasie tylko teoretyczne? W dodatku Polska znajdowała się w totalnym kryzysie i w przededniu transformacji ustrojowej, co oznaczało, że na żadną pomoc od nikogo nie można było już liczyć. Podróż do Afryki w tym czasie była zresztą dla wielu czymś wyjątkowo ekscentrycznym. Ja jednak chciałem zacząć karierę naukową antropologa i nie mogłem sobie pozwolić na czekanie na lepsze czasy.

Po drugiej wyprawie, na prośbę prof. Zofii Sokolewicz, opiekowałem się jej doktorantem z Sudanu, Bakrim Mirghanim al-Mekki, który obiecał swojej promotorce, że zaprosi mnie do Sudanu i postara się dla mnie o stypendium, w ramach wymiany naukowej, na Uniwersytecie w Chartumie. Wspomniany Bakri Mekki, poniekąd dzięki temu został doktorem, a ja, bynajmniej nie będąc najlepszym studentem, zostałem w maju 1988 r. asystentem w Katedrze. To moje doświadczenie, choć nie tylko ono, potwierdza spostrzeżenia antropologa brytyjskiego Nigela Barley'a - autora pracy Niewinny antropolog, w której zauważył: „[...] życie akademickie opiera się na kilku chybionych założeniach, które zakładają, że [...] kto jest dobrym studentem, ten będzie dobrym naukowcem. Kto jest dobrym naukowcem, będzie dobrym nauczycielem. A kto jest dobrym nauczycielem, zechce z pewnością przeprowadzać badania terenowe". Tymczasem „żaden z tych związków w rzeczywistości nie zachodzi" (Barley 1997: 7).

Na nadziejach związanych ze wspomnianym stypendium opierałem wszystkie moje plany, choć nadal nie rozwiązywały one problemu kupna biletu na samolot $i$, jak planowałem, ewentualnego utrzymania się co najmniej przez dwa lata w terenie, który powinien „zaliczyć”, jak uczono, każdy „prawdziwy antropolog”. 
W latach 80. niemal wszyscy w Polsce handlowali, a ja, choć zamiłowania do tego nie miałem, byłem jednak już po niezłej szkole "transkontynentalnego handlu obwoźnego" pod kierunkiem niedościgłego mistrza w tej sztuce - etnografa Jacka Łapotta, kierownika naszych wypraw afrykańskich. Gromadzenie środków na wyjazd rozpocząłem od pośredniczenia w sprzedaży obrazów artystów polskich do Szwajcarii. Zyskałem podczas tego zajęcia pewną wiedzę o handlu sztuką nowoczesną, ale niestety niewiele ostatecznie na tym zarobiłem. Posiadanych jednak oszczędności, tak jak podczas przygotowań do wcześniejszych wypraw, nie zamieniałem na wyjątkowo drogie w PRL czarnorynkowe dolary, lecz kupowałem różne dobra sprzedawane w Polsce po cenach urzędowych, z nadzieją, że ich ceny rynkowe w Sudanie okażą się wielokrotnie wyższe. Kupowałem wszystko, co można było wówczas kupić, a wymagało to wielu starań i znajomości; były to: materace, maszyny do pisania, maszynki do golenia, aparaty do masażu, prodiże elektryczne, kryształy, radzieckie aparaty fotograficzne marki „Smiena”, walkmany, NRD-owskie zegarki marki „Ruhla”, lornetki, żelazka i radia. Pozostało jeszcze przewieźć to wszystko do Sudanu samolotem, co było trudniejsze do wykonania niż ekspedycyjną ciężarówką. $Z$ dostaniem się na pokład sowieckich linii lotniczych "Aerofłot” miałem sporo kłopotów, gdy okazało się, ile faktycznie mam nadbagażu. Na szczęście pomógł mi znajomy konsul z ambasady radzieckiej ${ }^{3}$ Udało się i jakoś z tym wszystkim doleciałem do Chartumu. Na miejscu, ilekroć gotówka mi się kończyła, chodziłem po prostu od sklepu do sklepu, zachwalając, jak umiałem, któryś z tych towarów, a gdy znalazłem nabywcę, miałem za co przeżyć następny tydzień.

Wyjazd miał nastąpić na początku lipca 1989 r. Niestety 30 czerwca doszło w Sudanie do zamachu stanu, a władzę objął generał Omar Hassan Ahmad al-Bashir, popierany przez sudańskich fundamentalistów muzułmańskich. Wprowadzono stan wyjątkowy, a Bakri Mekki nalegał na przesuniecie daty wyjazdu, najpierw o miesiąc, potem o następny i jeszcze następny, a ja zacząłem się obawiać, czy kiedykolwiek w ogóle wyjadę. W Polsce rozpoczęto przygotowania do reformy Balcerowicza, co skutkowało dla mnie tym, że bilety na samoloty, mniej więcej od końca czerwca 1989 r., zaczęły drożeć dosłownie z dnia na dzień. We wrześniu wiedziałem już, że jeśli nie wyjadę natychmiast, to zabraknie mi pieniędzy nawet na bilet. $\mathrm{W}$ dodatku otrzymałem już urlop bezpłatny na uniwersytecie i nie mogłem sobie pozwolić na to, aby nie został on wykorzystany. Ostatecznie, zdeterminowany, chociaż wiedziałem, że moje stypendium jest ciągle niezałatwione, pojawiłem się w Chartumie 5 października 1989 roku. Nigdy nie żałowałem tej decyzji, gdyż tylko w ten sposób, będąc na miejscu, mogłem sam podjąć dalsze starania. $Z$ opóźnienia wyjazdu wynikała pewna korzyść: temperatura z 45 stopni spadła do 38 i można było już oddychać. Problemy jednak dopiero się zaczynały.

\footnotetext{
${ }^{3}$ Dziś może to dziwić, ale wówczas o tym, kto i z czym wejdzie na pokład Aerofłotu, decydowali ostatecznie nie pracownicy tej linii lotniczej, lecz pewni urzędnicy ambasady ZSRR, których status był dla mnie niezupełnie jasny.
} 


\section{Uniwersytet Chartumski. Przygotowania do badań}

Wjechałem do Sudanu na podstawie jednotygodniowej wizy dyplomatycznej, dzięki pośrednictwu Ministerstwa Spraw Zagranicznych. W Chartumie o przedłużenie jej na rok starałem się całe trzy tygodnie. Dzięki prof. Sayyidowi Hurreizowi, dyrektorowi Institute of African and Asian Studies na Uniwersytecie Chartumskim, otrzymałem oficjalne prawo do studiowania na tej uczelni, prowadzenia badań i legitymację studencką, choć bez miejsca w akademiku i obiecywanego kieszonkowego.

Cieszyłem się, że byłem w Sudanie, choć łatwo nie było. W Chartumie w tym czasie nawet chleb był reglamentowany, a ja nie byłem formalnie zarejestrowany i nie miałem prawa do jego przydziału. Brak było też cukru i papierosów. Zniknął również czarny rynek walutami. Obowiązywała godzina policyjna, na skrzyżowaniach ulic stały posterunki wojskowe, a w strategicznych punktach miasta nawet czołgi. Na wszystko, zwłaszcza na wyjazd poza Chartum, fotografowanie, nie mówiąc o badaniach w terenie, potrzebne były osobne zezwolenia z odpowiednich urzędów. Musiałem więc czekać na uregulowanie mojego statusu europejskiego badacza w Sudanie.

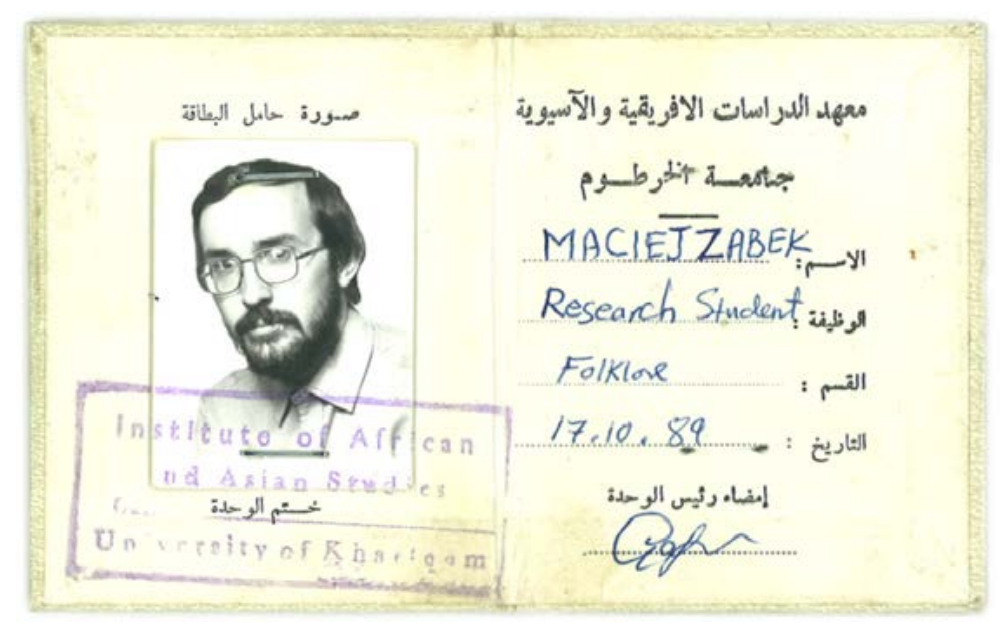

Fot. 1. Legitymacja badacza z Institute of African and Asian Studies. Fot. M. Ząbek

Na początku zatrzymałem się w mieszkaniu Bakriego, później jednak musiałem przeprowadzić się do pomieszczenia przy przedsiębiorstwie jego przyjaciela biznesmena. Mieszkałem tam razem z jego służącym Etiopczykiem. Właściciel, w ramach opłaty za kwaterę, kazał mi zakopywać rów odwadniający wzdłuż ulicy przed siedzibą jego firmy. Widok białego machającego na ulicy łopatą wzbudzał wśród czarnych przechodniów takie zainteresowanie, że w końcu właściciel zrezygnował z pobierania opłaty w ten sposób. Na chwilę przygarnęli mnie do swojego domu dwaj młodzi Egipcjanie, prowadzący interesy w Sudanie, którzy byli zainteresowani sytuacją w krajach Afryki i z tego względu szczegółowo 
wypytywali mnie, co, gdzie i za ile można w różnych krajach sprzedać. Później, pod koniec grudnia 1989 r., zaprosili mnie do siebie Polacy z przedsiębiorstwa "Budimex", budujący elektrownię w Chartumie Północnym. W zamian za prelekcje o Sudanie dla ich pracowników, na jakiś czas otrzymywałem w ich obozie polskie obiady, a warunki pobytu miałem niemal luksusowe.

Tymczasem sprawy na uniwersytecie przeciągały się w nieskończoność. Po długich korowodach obiecano w końcu, że zapewnią mi zezwolenie na badania, mieszkanie i wyżywienie, ale bez żadnych dodatkowych świadczeń. Na zrealizowanie tych obietnic musiałem poczekać. Planowano zakwaterowanie mnie w akademiku, ale później stwierdzono, że są tam, jak dla mnie, zbyt złe warunki. Nie znaleziono jednak szybko innego rozwiązania. Skromne obiady w stołówce akademika dla studentów medycyny zorganizowano mi dopiero 27 grudnia, o tyle za późno, że właśnie wtedy przeprowadziłem się na teren „camp Budimex”.

$\mathrm{W}$ walce $\mathrm{z}$ sudańską biurokracją pomagał mi mgr At-Tigani, młody pracownik wspomnianego instytutu, który, na zasadzie wymiany ze mną, miał przyjechać na studia doktoranckie na Uniwersytet Warszawski. Podobnie jak wielu innych pracowników chartumskiego Uniwersytetu, przez cały dzień nie robił absolutnie nic, poza codziennym przychodzeniem na prawie 8 godzin do "pracy" i udawaniem bardzo zajętego. Ostatecznie Tigani nigdy nie pojechał do Warszawy, gdyż znalazł w końcu lepszą dla siebie opcję w USA. Niemniej codziennie razem chodziliśmy do różnych biur uniwersytetu z rozmaitymi podaniami i zaświadczeniami, a wracaliśmy zawsze z niczym. Szybko zrozumiałem, że tutejsi urzędnicy, jeśli się ich jakoś nie przekona, nie zrobią absolutnie nic. Przyznać tylko trzeba, że nigdy niczego nie odmawiali, nigdy też nie mówili, że coś jest nie do załatwienia, tylko Insz Allah, bukra (Jeśli Bóg pozwoli, jutro). Gdy dochodziło do konfrontacji, każdy z nich twierdził, że to nie jego zadanie. Jeśli chodzi o załatwienie czegokolwiek, Arabowie sudańscy byli i są mistrzami uników. Najgorsi byli jednak "chłopcy” z tutejszej „bezpieki”, tzw. Security. Mocno kontrastowali z większością bardzo sympatycznych Sudańczyków - nigdy nie byli uśmiechnięci, ciągle nadąsani, nieuprzejmi i gburowaci, bardzo młodzi, niedbale ubrani, "klientów" zbywali zdawkowym "czego chcesz..., przyjdź jutro". Czekanie, czekanie, czekanie... każdego dnia poznawałem, czym jest afrykańskie „wytwarzanie czasu”.

Najważniejsze jednak, że dzień po dniu uczyłem się w ten lub inny sposób kultury tego kraju. Wolny czas wykorzystywałem przesiadując w bibliotece dawnego Gordon College, w której odkrywałem dla siebie mnóstwo interesujących książek, jakich w Polsce wtedy nie było. Z polskim księdzem Ryszardem Śliwińskim, którego odnalazłem w tutejszym Seminarium Katolickim, rozpocząłem naukę kolokwialnego języka arabskiego, prowadzoną przez jednego z tutejszych seminarzystów. Na uniwersytecie poznałem też kilku miejscowych badaczy o zbliżonych do mnie zainteresowaniach, m.in. geografów społecznych: dr. Husama Osmana, Sudańczyka, ale z Uniwersytetu w Bostonie i Japończyka dr. Nobuyuki Hori z Hiroszimy, a także niemieckich etnologów - Ulricha Braukämpera, który na początku mojego pobytu sprawował funkcję dyrektora naukowego 
Narodowego Muzeum Etnograficznego w Chartumie oraz później Andreasa Grueba z Uniwersytetu we Frankfurcie - którzy pracowali nad stworzeniem nowych wystaw w tym muzeum. Były to w zasadzie jedyne osoby, z którymi mogłem poważniej porozmawiać o moich planowanych badaniach.

Tym razem zamierzałem solidnie przygotować się do czekających mnie badań. Wiedziałem już, że nie pojadę w Góry Nuba, gdzie byłem z pierwszą wyprawą, ze względu na rozszerzającą się wojnę na Południu, która objęła także Południowy Kordofan. Drogę z El-Obeid na południe zamknięto już w Dillling (miasto na granicy tej prowincji). W tej sytuacji planowałem przeprowadzić badania wśród podobnej do ludów Nuba, słabo opisanej, refugialnej grupy Ingessana, zamieszkałej wokół Wzgórz Tabi, na północny zachód od miasta Kurmuk, przy granicy z Etiopią, w prowincji Błękitnego Nilu. Region ten wydawał się początkowo całkowicie bezpieczny. Tymczasem około 20 listopada rebelianci z Południowego Sudanu, atakując od strony terytorium wspierającej ich Etiopii, zdobyli Kurmuk. Moje plany w jednej chwili zostały znów pokrzyżowane.

W sytuacji panującej wówczas w Sudanie do wyboru pozostawała tylko Dolina Środkowego Nilu i rejony centralnego Kordofanu, które wówczas nie wydawały mi się szczególnie atrakcyjne. Niestety ówczesna etnologia warszawska niewiele miała do powiedzenia takim studentom jak ja, wyjeżdżającym w teren pozaeuropejski. Profesor Zofia Sokolewicz na pożegnanie kazała mi tylko czytać Ogrody koralowe... Malinowskiego, która to książka miała być moim przewodnikiem w trakcie badań. Za jej radą nawet zabrałem książkę ze sobą do Sudanu, choć nie na wiele w praktyce przydała mi się. Ekologia kulturowa, antropologia islamu, rozwoju czy polityki, które bardziej by tu były wskazane, miały się dopiero w Polsce rozwinąć w następnych dekadach. Moje myślenie o terenie determinowała przede wszystkim geografia; poszukiwanie nie tyle problemu badawczego, co odpowiedniego „miejsca”, które byłoby w jakiś sposób interesujące, różniące się od innych i które warte było poznania, natomiast temat studiów to rzecz, którą należało dopiero odkryć na miejscu.

Wspomniany wyżej dr Husama zainteresował mnie pasem maleńkich, ale "zielonych", dobrze nawodnionych kotlin (oaz) w Kordofanie, zwanych Cheiranem, które były jakby kręgosłupem większego terytorium konfederacji arabskich plemion Dar Hamid. To od niego dowiedziałem się po raz pierwszy o ekologii kulturowej i procesach pustynnienia zagrażających tamtejszym rolnikom. Pewne znaczenie miał też fakt, że jedynym antropologiem w tym terenie był przede mną Norweg Leif O. Manger, autor książki The Sand Swallows Our Land (Manger1981), a nikt nie napisał dotąd żadnej monografii o tutejszych Arabach z Dar Hamid. Nie miałem już czasu, żeby dużej się zastanawiać i w końcu podjąłem decyzję, że to właśnie te „oazy” Cheiranu i ich okolice staną się moimi „wyspami”, na których i wokół których zajmę się obserwacją zmian kulturowych po wielkiej suszy z lat 1984-85. Zezwolenie na badania i na podróż do centralnego Kordofanu otrzymałem już bez większych kłopotów. W dniu 9 stycznia 1990 r., po trzech miesiącach pobytu w Sudanie, byłem wreszcie w drodze na badania. 

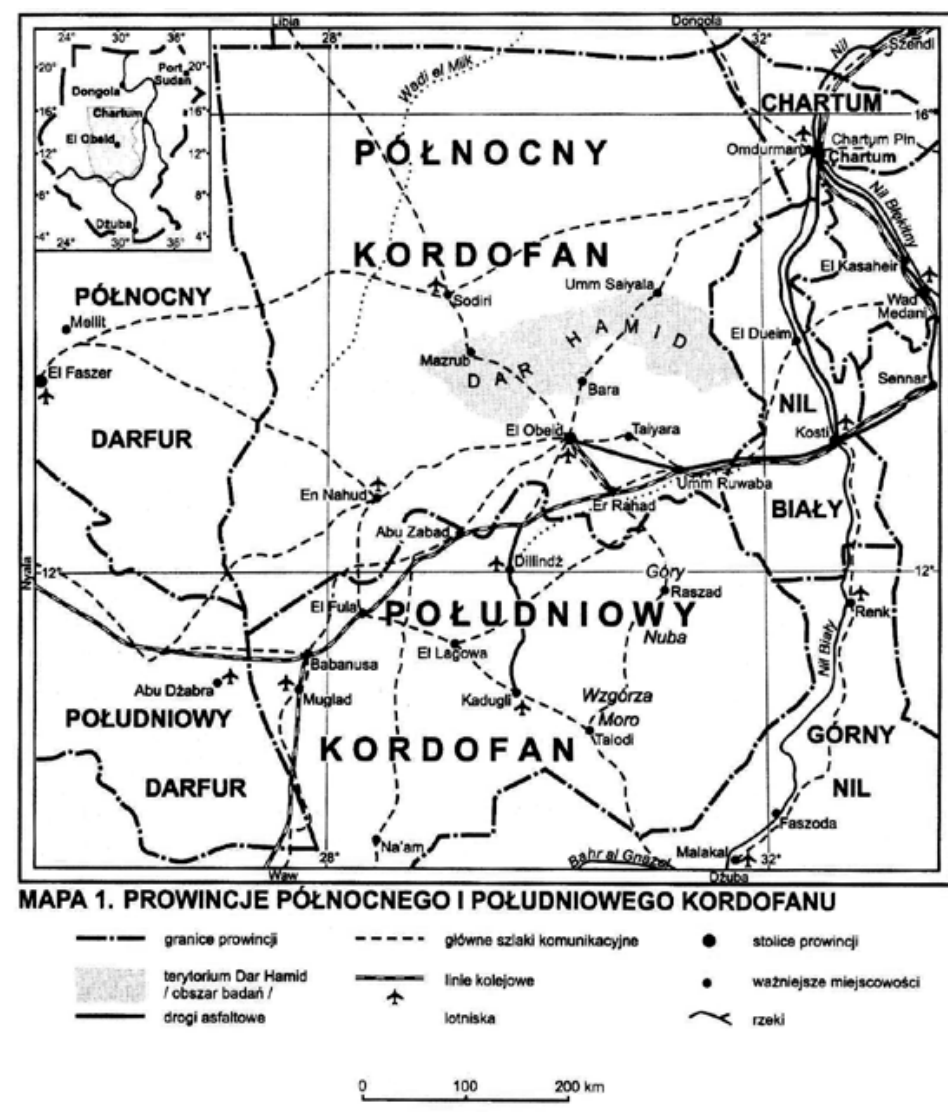

Fot. 2. Mapa prowincji Kordofan, z zaznaczeniem położenia obszaru Dar Hamid. Autor: M. Ząbek; podstawa mapy: Africa North East, Michelin 1987, skala 1 : 4000000

Przed wyjazdem, nie mając nic do stracenia, napisałem jeszcze pismo do Biura Współpracy z Zagranicą Uniwersytetu Warszawskiego, prosząc Rektora o wsparcie i informując go, że niestety nie otrzymałem obiecanego w ramach stypendium tzw. kieszonkowego, wynoszącego ok. 100 USD miesięcznie, co stanowiło połowę tamtejszych średnich zarobków; wspomniałem również, że mimo to $\mathrm{z}$ badań terenowych nie rezygnuję. Po dwóch miesiącach, gdy na krótko wróciłem w marcu do Chartumu, ku mojemu zaskoczeniu w polskim Biurze Radcy Handlowego, pełniącego również funkcje konsularne, czekało na mnie 250 dolarów udzielonych w formie „pożyczki” przez dziekana Wydziału Historycznego. Miałem ją spłacić po powrocie, pisząc artykuły. Suma była skromna, nawet jak na tamte czasy i warunki, rozumiałem jednak, że w Polsce, i to w okresie reform Balcerowicza, było to także duże poświęcenie ze strony Wydziału. Potraktowałem tę pomoc finansową jako dobry znak, świadczący że przynajmniej moja uczelnia nie chce rozwiązać ze mną umowy o pracę.

Ze strony Uniwersytetu Chartumskiego czekała na mnie kolejna miła niespodzianka, gdyż okazało się, że po pół roku znaleziono wreszcie dla mnie 
odpowiednie zakwaterowanie. Był to duży, choć zaniedbany, pokój z łazienką, w starym arabskim hoteliku zwanym Pink Palace, który w czasie II wojny światowej służył jako rezydencja cesarza etiopskiego Hajle Selasje. Jednakże pod koniec lat 80. hotel ten czasy świetności miał za sobą, jak wiele miejsc tego typu w Afryce z minionej epoki i nadawał się już tylko do remontu, pełnił jednak nadal funkcję hotelu uniwersyteckiego. Stało się to w samą porę, bo na "campie" Budimexu zabrakło już dla mnie miejsca. Nie wszystko jednak było pomyślne, gdyż okazało się, że nie mogę już korzystać z posiłków serwowanych w stołówce studenckiej.

\section{Podróże na miejsce i w terenie badań}

Pierwszy raz do Dar Hamid pojechałem trasą okrężną przez Kosti i El-Obeid, mając nadzieję, że zorganizuję sobie tam jakąś bazę, bliższą memu obszarowi badań, i ta podróż zajęła mi trzy dni. Później jeździłem już na skróty, przez pustynię via Bara (miasto będące stolicą Dar Hamid) i po około 24 godzinach docierałem już do celu. Dziś można tam dojechać w 9-10 godzin dobrym autobusem, drogą asfaltową przez Kosti i El-Obeid, wówczas jednak asfalt kończył się już w Kosti. Dalej można było tylko jechać „lorrą” (ciężarówką), na odjazd której czekało się godzinę lub dwie, siedząc już w niej, bo nigdy nie było wiadomo, kiedy czas nagle przyspieszy i kierowca zdecyduje się ruszyć. Niektóre z tych pojazdów pełniły funkcje autobusów, mając w części bagażowej zainstalowane miejsca do siedzenia, podczas gdy inne przestrzenie wypełnione były po brzegi rozmaitym towarem. Pasażerowie zaś gromadnie znajdywali sobie miejsce na tych pakunkach lub na dachu ciężarówki, jeśli oczywiście go posiadała. Te z dachem lubiłem bardziej, gdyż po pierwsze można było próbować negocjować cenę i ze 100 funtów sudańskich obniżyć np. aż do 20. Podróżni, dla których byłem pewną atrakcją, częstowali mnie w czasie drogi jedzeniem i piciem, co rekompensowało poniesiony wydatek. Po drugie, widok $z$ tej wysokości był wspaniały, a wiatr przyjemnie chłodził latem, choć zimą, zwłaszcza w czasie nocnej jazdy, temperatura spadała często do zera i bez śpiwora trudno było wytrzymać. W dodatku oprócz tumanów kurzu, które na półpustynnych bezdrożach wzbijały się w niebo, gdy wiał habub (przenikliwie zimny, niosący piasek wiatr znad Sahary), pył pokrywał każdy milimetr kwadratowy skóry i ubrania, a człowiek przybierał barwę brunatną niczym ściana pomalowana za pomocą pistoletu natryskowego.

W El-Obeid posłużyłem się listami polecającymi od księdza Ryszarda Śliwińskiego i biznesmena Faisala z Chartumu, skierowanymi do katolickiego biskupa w Kordofanie i Darfurze - Makrama Maxa, który przydzielił mi zakwaterowanie przy szkole prowadzonej przez Misjonarzy Kombonianów (MCCJ) z Malty. Było to dobre miejsce - po zameldowaniu się w miejscowym oddziale Security zawsze mogłem tam odpocząć, gdy już miałem serdecznie dość współżycia z miejscowymi, o którym jeszcze niedawno tak marzyłem. Innym ważnym dla mnie miejscem w El Obeid była apteka prowadzona przez Ibrahima, który studiował 


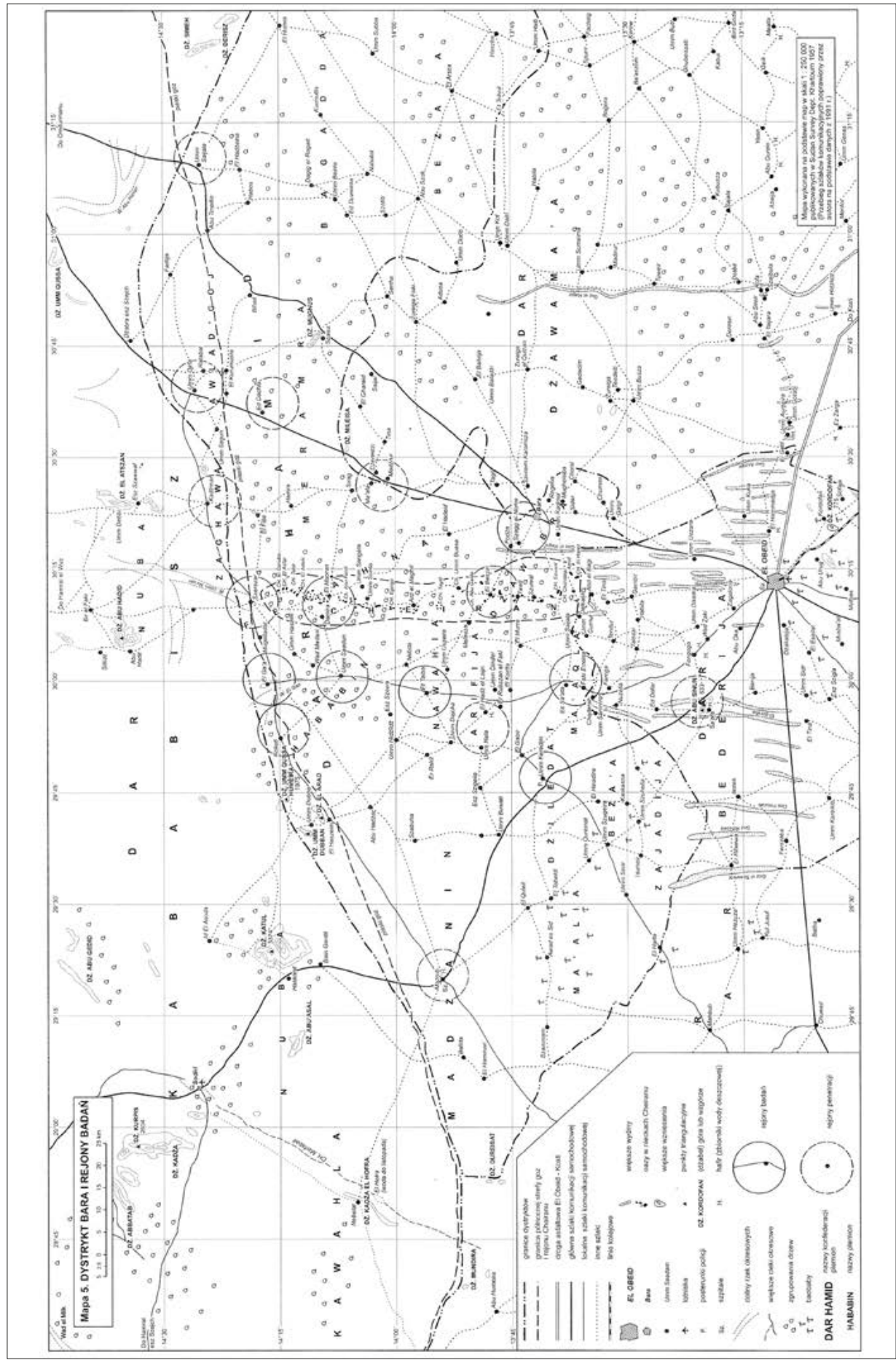

Fot. 3. Mapa Dar Hamid, z zaznaczeniem rejonów prowadzonych badań.

Autor: M. Ząbek; podstawa mapy: Sudan Survay Dept., Chartum 1957, skala 1 : 250000 
kiedyś farmację w Polsce i zapraszał mnie na obiady. Przesiadując w niej, poznałem chyba wszystkie ważne i interesujące osoby w tym mieście. Dziś być może właśnie to miejsce uczyniłby swoim "terenem”. Zapewne byłoby to i łatwiejsze, i bardziej obfitujące w różnorodne informacje, szczególnie o charakterze politycznym, ale wówczas nie wiedziałem nawet, że w ten sposób również można prowadzić badania etnograficzne.

Na terenie Dar Hamid takiego dogodnego miejsca niestety nie miałem, gdyż nie stać mnie było na wynajęcie tam jakiegokolwiek domostwa, jak robili to zwykle zachodni antropolodzy prowadzący w Afryce „badania uczestniczące”. $\mathrm{W}$ większych miejscowościach mieszkałem w rządowych tzw. resthouses, przeznaczonych dla państwowych urzędników. Były to zazwyczaj proste gliniane budynki, które wyglądały, jakby za chwilę miały się rozpaść, gdyż ich ściany nigdy nie trzymały pionu. Spałem tam zwykle razem $z$ innymi oddelegowanymi urzędnikami, policjantami lub nauczycielami, pochodzącymi z innych części Sudanu. Natomiast w małych wsiach mieszkałem zwykle w tradycyjnych cylindrycznych chatach tutejszych naczelników plemiennych (tzw. szejchów omda) lub nauczycieli. Chaty te, zbudowane na planie okręgu, były o wiele bardziej solidne niż rządowe resthouses, które w swych kubicznych formach zapewne miały być, jakże niedoskonałym, znakiem arabskości tego terenu. Wyraźna preferencja ludności miejscowej do tych kolistych kształtów była dla mnie dodatkowym (poza kolorem skóry) dowodem ich kulturowej afrykańskości.

Zazwyczaj nie musiałem tam płacić ani za nocleg, ani za jedzenie, choć czasami oczekiwano ode mnie prezentów. Głównie z tego powodu zmieniałem te miejsca, aby nie nadużywać gościnności moich gospodarzy, peregrynując od wsi do wsi na obszarze porównywalnym $z$ wielkością naszego Pomorza. Nie wiedząc jeszcze wtedy, że można prowadzić tzw. badania wielostanowiskowe (Marcus 1995), uważałem, że jest to dla mnie sytuacja niedogodna, obawiałem się, że z konsekwencji tej sytuacji trudno mi będzie się wytłumaczyć. Mimo to chciałem pisać o tym terenie nie tylko z perspektywy jednej wioski, ale możliwie najlepiej poznanego całego, w pewnym sensie, „regionu etnograficznego". Poza tym nie miałem większego wyboru, a problematyka pustynnienia i uwarunkowań ekologicznych lokalnej gospodarki wymagała zastosowania szerszej perspektywy. Do dziś uważam, że był to dobry wybór. Żałuję tylko, że nie byłem bardziej krytyczny wobec ówczesnych narracji badaczy zachodnich na temat samego pustynnienia, gdyż mógłbym bardziej skupić się na zrozumieniu tego zjawiska, a następnie na opisaniu miejscowego punktu widzenia na zachodzące zmiany.

Podróże w terenie na dłuższych trasach niekiedy również odbywałem ciężarówkami, o ile jakaś się akurat znalazła. Często ich nie było, bo - jak mówiono - armia zabrała wszystkie lorry do transportu na wojnę na Południu. Nawet jak wiadomo było, że jest jakaś lorry i odjedzie np. o godzinie 10.00, to w praktyce okazywało się, że odjechała, ale około 15.00. W trakcie podróży nigdy nie było wiadomo, ile razy zakopie się ona w piasku, ile razy trzeba będzie podkładać pod koła blachy albo, co gorsza, pchać ją i odkopywać. Mogła też się zepsuć i utknąć na dzień, dwa lub trzy, zanim ją naprawiono albo trzeba było czekać na przyjazd kolejnej, 
co często zdarzało się w miejscach bez wody i jedzenia. Pewnego razu utknąłem w takim miejscu na dwa dni, na szczęście mieliśmy większy zapas wody, a ludzi było mało. Przeżyłem wówczas po raz pierwszy w życiu kotkore (burzę piaskową). Wiało z południowego zachodu. Z daleka można było obserwować, jak zbliża się sięgająca od ziemi do nieba ściana czerwonego, kotłującego się w środku piasku. Gdy doszła do nas, schowaliśmy się, kładąc się na ziemi między skałami. Zapadła całkowita cisza, potem głęboka ciemność, a powietrze aż drgało z gorąca. Miałem poczucie, że jestem w piekle. Pół godziny później było już po wszystkim, spadł deszcz i było cudownie rześko. Ciężarówkę w końcu naprawiono i pojechaliśmy dalej. Innym razem, kiedy sytuacja była już naprawdę zła i nie mieliśmy wody, dostrzegłem nocą $\mathrm{w}$ oddali jakieś światła. Moi towarzysze podróży powiedzieli, że to baza geologów z Jugosławii, ale nie chcieli tam sami pójść, bo po drodze, jak mówili, są węże, skorpiony i hieny, a ci Chawadzia (Europejczycy) i tak ich na camp nie wpuszczą. Pewnie mieli rację, ale czułem, że mnie „bracia Słowianie” jednak wpuszczą, a pragnienie zdecydowanie osłabiało we mnie strach przed wężami. Nie myliłem się i po dwóch godzinach szybkiego marszu wypiłem chyba wiadro wody.

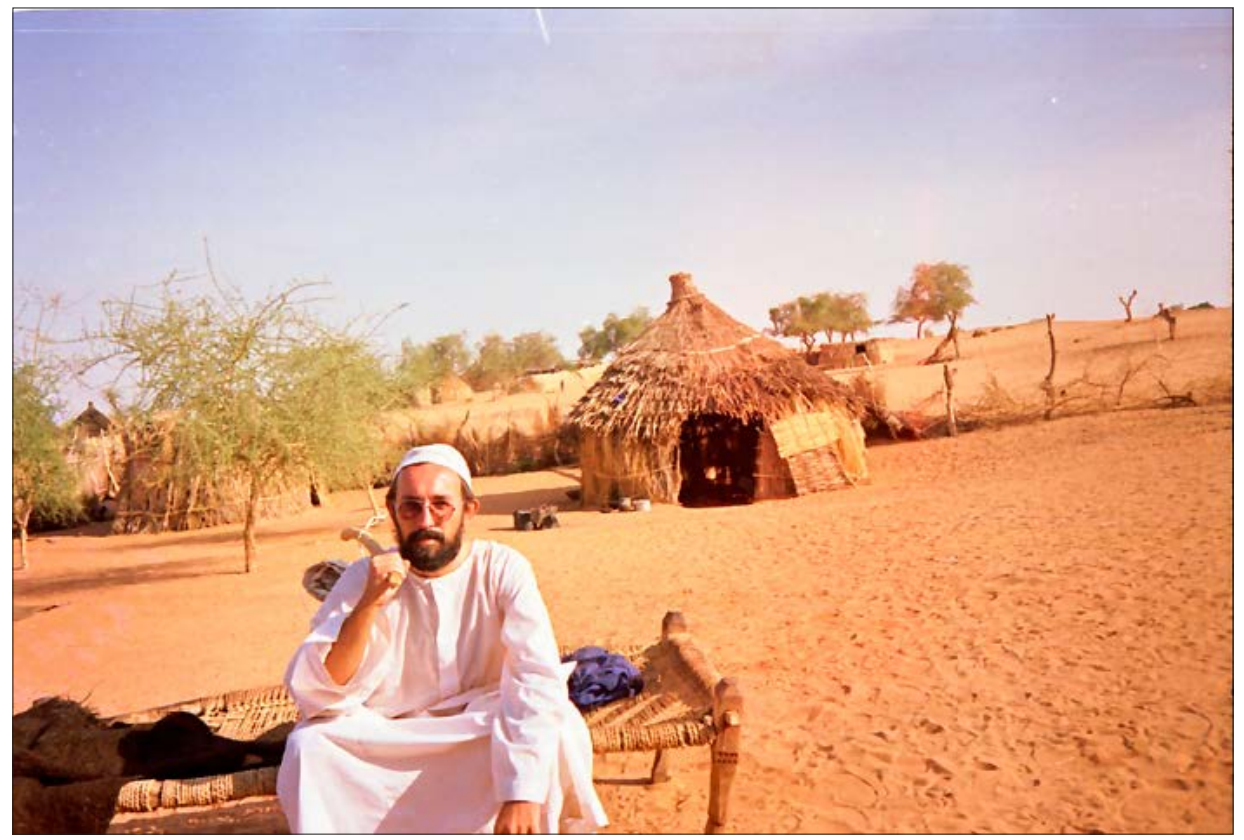

Fot. 4. Na wsi w Dar Hamid.

Fot. M. Ząbek; zdjęcie wykonane przy pomocy osoby miejscowej

Nie mając własnej terenówki jak profesjonalny europejski antropolog, najczęściej przyłączałem się do ludzi wędrujących na targowiska na osłach, rzadziej na wielbłądach, którzy łaskawie odstępowali mi jedno ze zwierząt, które niosło tylko towar. Jazda na ośle nie stanowiła większego problemu, chyba że wypiłem po drodze zbyt wiele merrisy (lokalnego piwa z prosa), którego w dzień targowy 
nigdy po drodze nie brakowało. Bardziej uważnym trzeba było być na wielbłądzie, zwłaszcza z uwagi na przechyły przy wstawaniu i dosiadaniu takiego wierzchowca, ale także wówczas, gdy puszczało się go w kłus (inochód) - wtedy trzęsło mną gorzej niż samochodem na największych wertepach.

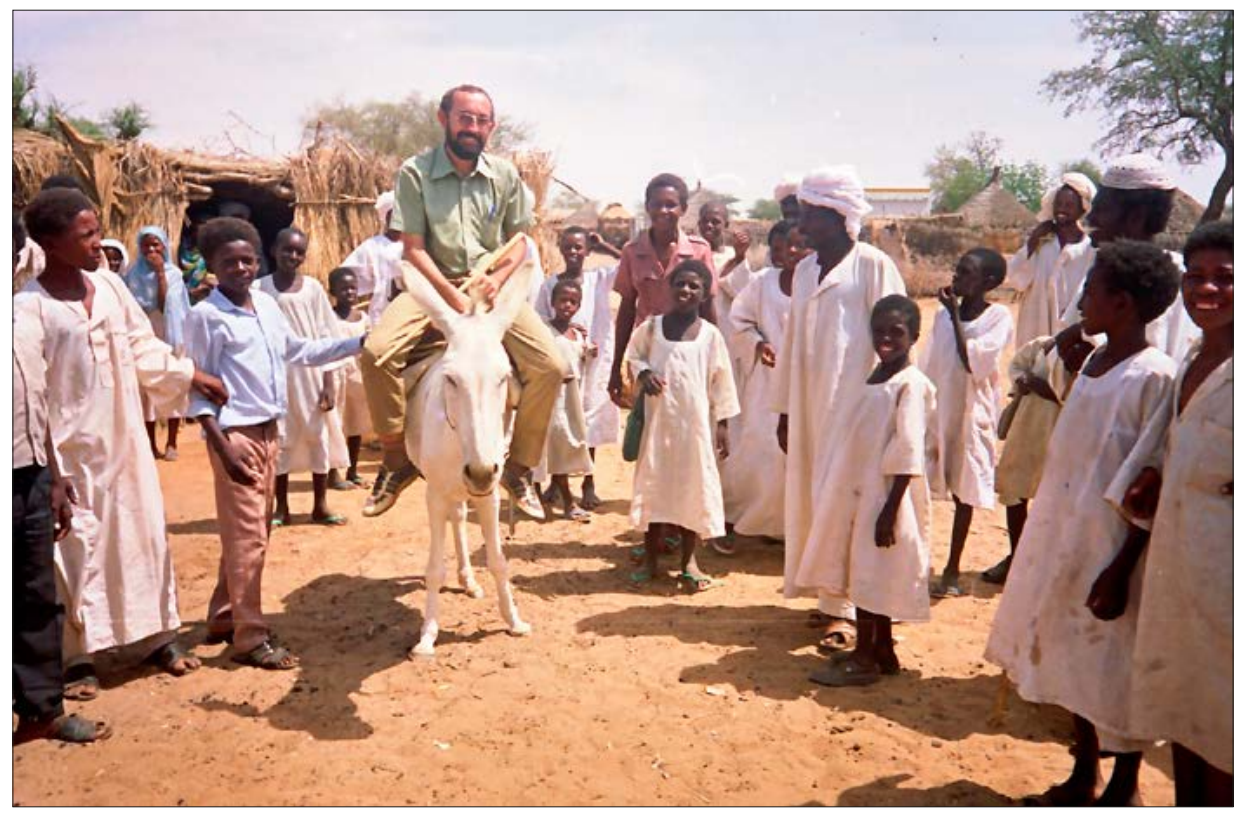

Fot. 5. Po przybyciu do jednej z wiosek w Dar Hamid.

Fot. M. Ząbek; zdjęcie wykonane przy pomocy osoby miejscowej

Czasami jednak trzeba było iść pieszo piaszczystym szlakiem, trzymając się tropów wielbłądów, osłów i ludzi, które niekiedy nagle rozchodziły się i łatwo można było zabłądzić. Najczęściej takie marszruty odbywałem w północnej części terytorium Dar Hamid, w czworokącie pomiędzy wsiami Umm Saadun, Damira, Szerszar, El Gaa i z powrotem do Umm Saadun. Dystans między nimi wynosił około $15-20 \mathrm{~km}$, co nie stanowiło większego problemu, jeśli tylko zachowało się prawidłowy kierunek. Latem było jednak tak wiele much, że oblepiały one całą głowę i twarz, i bez miotełki do odganiania trudno było sobie poradzić.

Zimą much nie było, ale za to wiał habub. Nie wiem, co było gorsze, chyba jednak muchy. Na szczęście nie było ich w chatach, widocznie nie lubiły ciemności. Niejednokrotnie ciągnął za mną ogromny rój much, ale gdy pochylałem się, aby wejść do chaty, ani jedna z nich nie wlatywała do środka, wszystkie pozostawały na zewnątrz.

Niekiedy można było spotkać po drodze pasterzy z wielbłądami, którzy częstowali mnie śmierdzącym skórą, ale pożywnym, kwaskowym mlekiem wielbłądzim, a zawsze mieli je w swych jukach. Przy innej okazji można było napić się kawy w chacie jakiejś starej samotnej kobiety i trochę tam odpocząć. Trudniej było wędrować nocą, wówczas kierowałem się w stronę góry El-Gaa 
widocznej z daleka w poświacie księżyca i ognisk w zagrodach. Gdy dochodziłem do pierwszych domostw, to już tam pozostawałem na resztę nocy. Gospodarze, początkowo przestraszeni niespodziewanym najściem Chawadzii, który zjawiał się jak duch, pokrzyczeli trochę, ale uspokajali się w końcu i zawsze częstowali wodą pachnącą spalonym drzewem, słodką herbatą, także skromnym jedzeniem, a gdy było zimno, dawali i koc do okrycia.

Wszyscy moi gospodarze byli na ogół niezwykle serdeczni i gościnni, choć oczywiście na końcu oczekiwano nie tyle pieniędzy, co prezentów. Czasami wręcz o nie otwarcie proszono. „Daj mi nóż, długopis, latarkę, aparat fotograficzny, zdjęcie, koszulę..." W niektórych okolicznościach oczekiwano ekstra podarunków, ale w ostateczności wystarczyło cokolwiek, choćby papieros. W zależności od tego, co miałem ze sobą i na ile wyceniałem ich gościnność, dawałem, co mogłem, ale zdarzało się też, że musiałem im odmówić.

\section{Specyfika kontaktu}

Po trzech miesiącach codziennych rozmów z Sudańczykami w Chartumie, pierwszy kontakt z Arabami z Dar Hamid nie wywołał już większego zaskoczenia. Nie potrzebowałem tu w zasadzie „odźwiernego”. Arabów sudańskich cechuje brak dystansu, wielkie otwarcie na obcych i sławna gościnność beduińska. Szejch wszystkich szejchów, nazyr Dar Hamid, El-Bet Muhammed Tumsah, zaakceptował mnie niemal natychmiast, a powołanie się na niego otwierało domostwa we wszystkich kolejno odwiedzanych wsiach. W tym więc sensie to on był moim odźwiernym. Załatwianie spraw przez równoległy system administracji rządowej było o wiele mniej skuteczne i ograniczało się tylko do kwestii formalnych (przybicia pieczątek i odnotowania mojego pobytu w aktach). Wielokrotnie odwiedzałem Muhammeda w jego rodzinnej wsi Umm Saadun, należącej do plemienia Hababin, gdzie wprowadzał mnie w miejscowe relacje.

Drugą kluczową dla mnie osobą był Omar Tigani, szejchomda plemienia Ferahna z Damiry. Zaznajamiał mnie z miejscowymi zwyczajami, wyjaśniając wszystko dokładnie i zapisując patykiem na piasku niektóre arabskie terminy i zwroty, później kazał mi je powtarzać i uczyć się na pamięć. Z dziesiątkami innych osób, z którymi się spotykałem, też nie miałem większych problemów, choć nie brakowało momentów dla mnie trudnych. Nie zawsze potrafiłem w odpowiednim czasie odróżnić ważne osoby od mniej ważnych, a w dodatku zapamiętać ich powtarzających się imion, co było jedną z ważniejszych rzeczy w utrzymywaniu poprawnych relacji z otoczeniem.

Zazwyczaj dzień zaczynał się podobnie jak na polskiej wsi. Budziło mnie pianie kogutów, gdakanie kur, ryk osłów, beczenie owiec, odgłosy ludzi i ogromne ilości much, jeśli spałem latem pod gołym niebem. Brakowało oczywiście ujadania psów i kwiczenia świń, no i tego swojskiego zapachu obornika, świeżego siana i trawy. Sługa przynosił mi nie więcej niż pół litra wody w małej konewce do umycia się po załatwieniu potrzeb naturalnych, a potem gospodarz zapraszał 
na herbatkę z mlekiem dla poprawy samopoczucia. Śniadanie, jeśli w ogóle było, to często dopiero około południa. Potem można było wyjść na targ, wypić znowu herbatkę, pochodzić po wsi i pogadać z ludźmi. Po południu czekało na mnie zwykle wiadro wody, miednica, kubek, i mogłem się wówczas „wykąpać”. Potem podawano „obiadokolację". Po zmierzchu rozmowy z domownikami ciągnęły się jeszcze do późna w nocy.

Należało się przede wszystkim wykazać wielką cierpliwością, i to nie tylko przez pierwsze godziny, ale często i dni, po przybyciu do wioski. Wszędzie, gdzie się pojawiłem pierwszy raz, byłem lokalną sensacją i każdy z mieszkańców chciał się ze mną przywitać, dotknąć i porozmawiać. Europejczyków w tych miejscach widywano wówczas bardzo rzadko, a żaden z nich nigdy u nich nie mieszkał. Wszystko wzbudzało ich zainteresowanie: mój plecak, aparat fotograficzny, okulary, długopis, latarka, buty, nawet ich własny tytoń do żucia (tombak), no i papier toaletowy, który, gdy wytłumaczyłem do czego służy, wzbudzał w nich wyjątkową odrazę. Nic przed ich oczami nie dało się ukryć, wszystkiego musieli dotknąć, obejrzeć i spróbować. W końcu byli ciekawi, podobnie jak i ja, choć czasami miałem ich już serdecznie dość. Przez pierwsze dni zwykle to nie ja ich wypytywałem, tylko oni mnie. Po obowiązkowym rytuale muzułmańskich powitań, które powtarzane kilkakrotnie trwały kilka minut, i podaniu mi wody, zaczynano od ustalenia, kim jestem. Pytano: „Jakie jest twoje imię, imię twojego ojca, skąd jesteś? Gdzie jest twój kraj? Dokąd idziesz? Gdzie byłeś? Co robisz? Dlaczego to robisz?".

Polskę oczywiście brano za Holandię (Bolanda-Holanda), którą kojarzono $\mathrm{z}$ importowanym tu mlekiem $\mathrm{w}$ proszku i czasami zupełnie nie miało sensu tłumaczenie, co to jest Polska. Zagadywano zwykle po arabsku: „Czy w twoim kraju jest dużo krów, dużo mleka i trawy? Czy jest taki piasek, jak u nas? Jaka jest u was ziemia? Jakie jest rolnictwo? Czy są osły, wielbłądy, barany, kozy?". Pytali też: „Kiedy jest w twoim kraju pora deszczowa? Czy są tam hafiry [zbiorniki retencyjne]? Skąd kobiety czerpią wodę? Czy są tam jakieś rzeki? Czy jest asida [rodzaj gotowanej brei z prosa spożywanej z sosami, tutejszy odpowiednik naszego chleba codziennego]? Jak uważasz, czy lepsze jest jedzenie ręką niż łyżką?" - z nieukrywaną nadzieją na odpowiedź, że ręką.

Moje odpowiedzi (zwykle już po angielsku) budziły zaskoczenie, niedowierzanie i niekończące się komentarze. Dzięki temu i ja dowiadywałem się wiele o tutejszym życiu. Nie do końca wówczas rozumiałem, że już w tym momencie „robię etnografię", dlatego też czekałem z niecierpliwością na koniec tych pytań, aby w końcu odejść z kimś na bok i przeprowadzić z nim taki wywiad, jakiego uczono mnie na studiach.

Po pewnym czasie, po jedzeniu i herbatce, wieczorem lub na drugi dzień, przechodzono do pytań bardziej osobistych. Dopytywano się: „Ile masz lat? Czy jesteś żonaty? Dlaczego nie jesteś? A jak będziesz żonaty, to ile chciałbyś mieć dzieci? Ile chciałbyś mieć żon? Czy ożeniłbyś się z Sudanką? Jakiej jesteś religii? Dlaczego nie chcesz przejść na islam?". To ostatnie pytanie było zwykle kluczowym. Zadawali je wszyscy, od szejchów po potomków byłych niewolników, co 
sprawiało, że temat religii stawał się w tych rozmowach centralnym zagadnieniem. Ta kwestia naprawdę ich interesowała, w przeciwieństwie niestety do mnie, co sprawiało, że na wiele z zadawanych pytań nie potrafiłem właściwie odpowiedzieć. Choćby takich: „Czy wierzysz w Boga? Dlaczego nie modlisz się z nami? Dlaczego chrześcijanie nie uznają Mahometa, skoro my uznajemy Jezusa? Czy wiesz, że Jezus nie umarł na krzyżu? W którym kierunku się modlicie?".

W kolejnych dniach indagowano mnie już pod kątem skrywanych często marzeń o migracji lub posiadaniu białej żony, czego nie wyrażano tak bezpośrednio i oczywiście nie przy wszystkich. Takie pytania zadawali tylko młodzi, względnie wykształceni mężczyźni (nauczyciele lub urzędnicy), a rozmowy na ten temat toczyły się już wyłącznie po angielsku. Podpytywano mnie: „Ile płaci się w twoim kraju za żonę? Czy łatwo dostać wizę do twojego kraju? Jak długo leci się samolotem z Chartumu do Polski? Czy można dostać tam pracę? Ile się zarabia? Czy w Twoim kraju są muzułmanie? Ilu ich jest? Jakim językiem mówi się w Twoim kraju? Czy można tam się ożenić? Jak wygląda w twoim kraju wesele? Czy polska kobieta nie przyjechałaby do naszej wsi? Dlaczego sądzisz, że nie chciałaby tu zostać?".

Interesowało ich również, jaką mam o nich opinię, jak postrzegam Sudan. „Jak nas widzisz?" - pytano. Oni sami, uważający się za "synów Hamida”, byli we własnym mniemaniu nie tylko najlepszymi Sudańczykami, ale w ogóle „najprawdziwszymi” Arabami na świecie, pochodzącymi prosto z Hidżazu. Twierdzili, że przez Tunis i Saharę przeszli do Kordofanu. Ich zdaniem, „Faraoni” (Egipcjanie) nie byli prawdziwymi Arabami, a Saudyjczyków uważali za niewykształconych i wyjątkowo głupich. W ich przekonaniu, plemiona Hamida były tak naprawdę "białe”, choć - jak przyznawali (trochę ze wstydem) - nie w takim stopniu jak ja, gdyż w przeszłości mieli dużo czarnych niewolnic. Imponowali mi naprawdę znajomością swych genealogii, geografii wschodniej Sahary i astronomii. Gwiazdy i ich konstelacje odróżniali bezbłędnie, dzięki czemu poruszali się pewnie w terenie. Pytali też: „Czy chciałbyś zostać z nami na zawsze? Czy przyjedziesz do nas raz jeszcze?". Były też pytania zadawane tylko po to, aby porozmawiać trochę po angielsku, a nie po to, aby się czego dowiedzieć? Na przykład: „Czy u was jest taki sam księżyc? Jaka jest różnica między ludźmi białymi a czarnymi?". I tak dzień w dzień, aż do momentu, w którym zainteresowanie otoczenia moją osobą nagle się kończyło, co z jednej strony przynosiło mi chwilę wytchnienia, z drugiej jednak musiałem wtedy sam poszukać rozmówców.

Jak prawie wszędzie między młodymi mężczyznami pojawiał się w końcu temat polityki i seksu. Pierwszy temat narzucał się sam, pod wpływem zachodzących w świecie wydarzeń, nawet tam w Dar Hamid, budzących szereg kontrowersji, jak poczynania władz wojskowych w Sudanie, znaczenie wpływów Braci Muzułmańskich, rola prawa islamskiego, nieustanne starcia zbrojne w Południowym Sudanie, czy pierwsza wojna w Zatoce, która wybuchła w trakcie mojego pobytu i oczywiście rola Izraela w tych konfliktach. Próbowano ustalić, co sądzę o konflikcie między Irakiem i Stanami Zjednoczonymi, jaka jest moja opinia o Saddamie Husajnie, prezydencie Iraku, czy o dyktatorze libijskim Mu'ammarze 
al-Kadafim, czy też o przywódcy rebeliantów z Południa - Johnie Garangu albo o sudańskim prezydencie generale Omarze El-Beshirze. Czasami twierdzono, że Południowcy to dobrzy ludzie, a Garangowi chodzi o dobro całego Sudanu. Innym razem próbowano przekonać mnie o braku cywilizacji na Południu i dzikości, czy nawet bestialskości tamtejszych ludów, w szczególności Nuerów i Dinka. Co do rządów w Sudanie, ich opinie były podzielone. Wielu nie podobały się niektóre zakazy szariatu. W końcu np. merise (piwo z prosa) pito zawsze, nawet w okresie rządów Mahdiego uznawanych za fundamentalistyczne. Przekonywano, że ,jest pożywna i zawiera dużo witamin”. Uważano, że jeśli „niektóre duchy (zar, czy kadziur) wywołują choroby, to trzeba je przebłagać", dlaczego więc rząd zakazuje obrzędów zar? Wskazywano też na to, jak niewiele władza czyni dla poprawy życia zwykłych Sudańczyków.

Byli wśród nich także i tacy, zwłaszcza bardziej wykształceni i pełniący jakieś funkcje publiczne, którzy uważali, że przywódcy, jak wspomniany Kadafi, Saddam czy ich własny El-Beshir, to „dobrzy arabscy nacjonaliści”, przeciwstawiający się wyzyskowi Zachodu, (których przedstawicieli nazywano krzyżowcami) oraz agresji Izraela na arabskie ziemie. „Nacjonalizm”, ku memu zaskoczeniu, był pojęciem postrzeganym przez wykształconych Sudańczyków pozytywnie, gdyż łączono go z poczuciem własnej „godności”, podobnie jak każdy opór wobec polityki Zachodu wspomnianych wyżej polityków.

Jeszcze większe emocje w tamtym czasie budziły echa fatwy (opinii prawnej), którą w 1989 r. wydał imam Chomeini w sprawie autora Szatańskich wersetów Salmana Rushdiego. Imam apelował do wszystkich muzułmanów „o wypełnienie boskiego nakazu i oczyszczenie świata z wynajętych (przez Zachód) diabłów, jak Rushdie". W oczach Sudańczyków przy pisywanie ukochanej żonie Proroka rozwiązłości, twierdzenie, że Koran został napisany przez ludzi i cytowanie z niego fragmentów świadczących o politeizmie, było oczywistym bluźnierstwem, które naprawdę chcieli pomścić, a ja byłem często jedynym Chawadziq̨ w ich zasięgu, na którym mogli część tych emocji przynajmniej w symboliczny sposób wyładować. Wszystkie te opinie były wówczas dla mnie dużym zaskoczeniem, nie rozumiałem ich i zupełnie niepotrzebnie próbowałem wchodzić z nimi w polemikę, na szczęście ich tolerancja była naprawdę duża. Tym bardziej, że o ile na początku (w 1989 r.) wielu jeszcze potępiało Irak i nie krytykowało zdecydowanie polityki USA, to w miarę upływu czasu (w 1991 r.) potępienie Ameryki, wysyłającej swoich żołnierzy na święte ziemie islamu, stawało się coraz silniejsze i było prawie powszechne. Atmosferę podsycała propaganda rządowa w audycjach radiowych, których część bogatszych Arabów, posiadających radia tranzystorowe, słuchała z uwagą i rozpowszechniała. Saddam Hussein w ich oczach stał się bohaterem, który rzucił wyzwanie bogatym Chawadzia. Powszechna była opinia, że „jest to bardzo odważny człowiek, a Amerykanie są podłymi tchórzami". Kiedy w styczniu 1991 r. zaczęła się wojna w Zatoce, nie tylko w Chartumie i El-Obeid, ale we wszystkich wsiach w Dar Hamid organizowano demonstracje młodzieży szkolnej, które przekształcały się w prawdziwe seanse nienawiści, a ja w tym czasie dwukrotnie musiałem uciekać, gdy rzucano we mnie kamieniami. 
Co do drugiego tematu, o którym wyżej wspomniałem, sporym szokiem było dla mnie to, że pojawiał się on często w kontekście dyskusji o religii. Zagadnienie, jak powinien zachowywać się mężczyzna wobec kobiety, i co ja o tym sądzę, było dla nich także interesujące. Z którą z kobiet - pytano prowokacyjnie - seks jest lepszy: z tą, której wagina jest „mokra”, czy z tą, której jest sucha? Jaki penis jest lepszy: obrzezany czy nieobrzezany? Okazało się przy tym, że słownictwo dotyczące spraw genitalnych było u nich o wiele bogatsze niż w Polsce. W trakcie tych rozmów pojawiał się także wywód o potrzebie „oczyszczania”, czyli wykonywania genitalnych okaleczeń i obrzezań. Na tego rodzaju dyskusje też nie byłem przygotowany.

Z samymi kobietami moje relacje w Dar Hamid były wprawdzie dużo rzadsze, ale wynikały raczej ze zwykłej bariery występującej między płciami niż z jakiejś twardej islamskiej separacji kulturowej, o której wcześniej słyszałem, i która zresztą pojawiała się, ale w innych trochę kontekstach i środowiskach. Miałem, ku mojemu zaskoczeniu, niezwykle udane rozmowy z niektórymi starszymi kobietami, zwłaszcza z jedną z akuszerek, która dokładnie wyjaśniła mi sposoby odbierania porodu. Innym razem było to spotkanie z szejchą zar w Umm Keredim, dzięki czemu mogłem obserwować obrzędy "Zar" od początku do końca. Niezwykły był też pobyt, jeszcze w styczniu 1990 r., u trzech młodych nauczycielek we wsi Ed-Dahla. Dziewczyny były zachwycone moim pojawieniem się. Mieszkały same w obszernej zagrodzie z dala od wsi. a dochodzącego do nich służącego wypędziły na czas mojego pobytu. Żartom i śmiechom nie było tam końca. Najważniejszą jednak z kobiet dla moich badań była w Dar Hamid, jedyna córka nazyra, też młoda nauczycielka, ale nieformalnie niemal tutejsza „księżniczka”. Była ona jedną z najbardziej inteligentnych osób, jakie tam poznałem. Kilka razy była moją tłumaczką i interpretatorką wypowiedzi różnych ważnych person w Bara (stolicy Dar Hamid) i Umm Saadun (rodzinnej wsi nazira). W spotkaniach z tymi osobami ona także czasami uczestniczyła i to jako jedyna z młodych kobiet. Rozmawialiśmy wówczas o możliwości rozwoju regionu. O tym, że nie można już liczyć na porę deszczową i należy rozwijać nawadniane ogrodnictwo, a przede wszystkim uprawę warzyw, co jednak wymaga inwestycji w budowę studni, pomp solarnych i rozwoju transportu, aby móc szybko dostarczyć np. pomidory na rynki w dużych miastach.

Poza wspomnianymi wyżej rozmowami próbowałem, jak mi się wówczas wydawało, prowadzić badania także bardziej usystematyzowane i transparentne, a poza tym umożliwiające tzw. szybkie poznawanie faktów. Nie wiedziałem wtedy, że w badaniach antropologicznych nie tylko o takie fakty chodzi. Wykorzystałem w tym celu, pożyczony od Bakriego, egipski podręcznik do etnografii (nazywanej tam folklorystyką), zawierający dziesiątki kwestionariuszy w języku arabskim na różne tematy. Pytania te powieliłem, przystosowując je trochę do moich celów, a będąc w terenie, dawałem je do wypełnienia pisemnego różnym napotkanym osobom. Zebrałem ponad tysiąc (przeprowadzonych ze 162 osobami) tego typu ankiet, które później tłumaczyłem razem z moimi sudańskimi przyjaciółmi z Chartumu. Rezultaty tej metody były jednak mniejsze niż praca 
włożona w ich przygotowanie. Otóż wypełniane one były bardzo pobieżnie i nie do końca nadawały się do statystycznego opracowania. W wywiadach otwartych z kolei natrafiałem na spore przeszkody komunikacyjne, oczywiście językowe, ale również mentalne i kulturowe. $W$ tym zakresie to islam postrzegałem jako główny problem, gdyż moi arabscy informatorzy nie chcieli mówić o swoich prawdziwych codziennych obyczajach, zabranianych im przez szariat. Prawie nikt nie chciał ze mną rozmawiać o wróżbach, czarach czy magii. Czasami musiałem naprawdę namęczyć się, aby coś wydobyć od moich rozmówców. Nieraz wydawali mi się wyjątkowo tępi. Sądziłem czasem, że muszę wręcz na nich nakrzyczeć, aby choć trochę się postarali i odpowiedzieli na moje pytania. Zresztą rozmowy z Arabami są nierzadko bardzo ekspresyjne i w niektórych sytuacjach takie zachowanie było nawet skuteczne. Bywało jednak, że z mojego pokrzykiwania tylko się śmiali. Śmiano się ze mnie zresztą bardzo często, gdyż, według nich, zadawałem przeważnie głupie pytania. Prawda jest też taka, że kiedy było naprawdę bardzo gorąco (powyżej 40 stopni), po prostu byłem zmęczony nieustannym z nimi obcowaniem i nieraz nawet nie starałem się być uprzejmy. Przyznam też, że uprawianie etnografii terenowej nie zawsze okazywało się dla mnie przyjemnym zajęciem. Trzeba było mieć „boską cierpliwość i końskie zdrowie”. Dlatego po dłuższym czasie przebywania sam na sam z Sudańczykami, nawet sporadyczne kontakty z Europejczykami sprawiały mi wręcz fizyczną przyjemność. W ten sposób w Afryce okazywało się, że jednak jestem Europejczykiem. $\mathrm{W}$ rozmowach $\mathrm{z}$ „Białymi” wszystko stawało się bardziej jasne, nic mnie nie zaskakiwało i wiadomo było od razu, o co chodzi.

W Bara poznałem m.in. pracującego tam prawnika Fredrika von Homeyera ze Szwecji, z organizacji pozarządowej. Zżył się on z miejscowymi Arabami i poznał ich o wiele lepiej niż wielu innych pracowników z organizacji pomocowych, stąd mieliśmy sobie wiele do powiedzenia. Namówił mnie, abym przebrał się w miejscowy strój, w którym sam także chodził, gdyż uważał takie zachowanie za wyraz akceptacji, szacunku i partycypacji w kulturze miejscowej. Uczyniłem tak jak mówił, choć od początku miałem wątpliwości, czy tzw. cross-dressing jest postępowaniem naprawdę etycznym i czy do czegoś jest mi potrzebny. $Z$ uwagi na mój status materialny, zachowanie i poniekąd ówczesny wygląd, często dla niektórych Sudańczyków, którzy widzieli mnie pierwszy raz, i tak byłem Europejczykiem. Inni podejrzewali mnie, że jestem tak naprawdę np. Pakistańczykiem lub Irańczykiem. Nie miałem też zamiaru sygnalizować otoczeniu w jakikolwiek sposób, że jestem podatny na konwersję, a przecież strój muzułmański był w końcu jej znakiem. Toteż zgadzam się z Ryszardem Vorbrichem, który pisze, że "cross-dressing daje tylko złudne poczucie „zadomowienia” i przekroczenia granicy między "zewnątrz“ a "wewnątrz«" (Vorbrich 2020: 282-283). Nie musiałem w celu nawiązywania kontaktu z Sudańczykami szukać specjalnego fortelu - jadłem, spałem, podróżowałem i żyłem razem z nimi, nigdy nie będąc sam, przez cały spędzony tam czas, a gdybym chciał już przekroczyć naprawdę wszystkie granice, które mi zostały, to wystarczyło tylko przejść na islam. Strój sudański czasami jednak 
nosiłem, ale ze względów tylko praktycznych, gdyż sprawdzał się doskonale w czasie, gdy było naprawdę goracco i podczas pobytu we wsiach. W trakcie podróży jednak wygodniejsze były spodnie i koszula.

\section{Religia, jedzenie i problemy ze zdrowiem}

Główną osią w relacjach z Arabami był zawsze dyskurs religijny. Dziś żałuję, że go nie doceniałem, że wchodziłem w niego poniekąd z przymusu, z uprzejmości, dla podtrzymania przyjacielskich relacji, gdyż uniknąć go się nie dało. W zasadzie byłem bliski konwersji tylko po to, aby dano mi spokój, przekonałem się jednak, że taka decyzja niechybnie pociągnęłaby wiele innych zobowiązań, wymaganych zwłaszcza od neofity. Stąd ostrożnie chroniłem swą chrześcijańską tożsamość, broniąc niektórych religijnych dogmatów, tak jak umiałem. O islamie myślałem, że wiem o nim prawie wszystko, podczas gdy tak naprawdę nie wiedziałem niczego. Czym jest ta religia, zrozumiałem dopiero, żyjąc wśród muzułmanów. Odkryłem to jednak dla siebie zbyt późno. Nie wiedziałem przede wszystkim, że islam to nie tylko wiara, a może przede wszystkim nie tyle wiara, co raczej prawo, zwyczaj i kult (rytuał). W Dar Hamid poznałem dopiero, że dla moich rozmówców o wiele mniej ważne jest to, w co wierzę niż to, jak się zachowuję, bowiem zachowania, i to w najmniejszych szczegółach, były regulowane poprzez islam lub wchodzącą w jego skład lokalną tradycję.

Zrozumiałem też z czasem, że akceptowano mnie tylko dlatego, że na ogół starałem się być posłusznym uczniem i we wszystkich codziennych rytuałach, od wychodzenia do ubikacji, mycia się, jedzenia, po reagowanie na różne wydarzenia, dokładnie naśladowałem miejscowe wzory. Nie wiedziałem wówczas, że to $\mathrm{w}$ ten sposób, a nie przez studiowanie Koranu, należy uczyć się zasad islamu. Ratowało mnie to z różnych kłopotów i pozwalało zachować dobre relacje z moimi gospodarzami. Wystarczyło jednak, że przypadkiem zrobiłem coś nie tak, jak należało, np. nie tą nogą wyszedłem z ubikacji, nie na czas się umyłem, nie $z$ tego miejsca miski, co powinienem, zgarnąłem palcami jedzenie, aby od razu zwrócono mi uwagę lub nawet wywołano awanturę. Zdarzyło się tak, gdy pewnego razu, z powodu ciemności panującej w małej komórce przeznaczonej do mycia, zostawiłem otwarte do niej drzwi, a przechodząca żona gospodarza ujrzała mnie tam rozebranego. Podobnie niezręczna sytuacja miała miejsce, kiedy to wszedłem do czyjeś zagrody, nie uprzedzając gospodarzy zwyczajowymi klaśnięciami w dłonie lub gdy przeszedłem przed modlącym się człowiekiem, nie położywszy wcześniej przed nim kija, jako symbolicznej rzeczy rozgraniczającej przestrzeń sakralną od pozostałej i nieopatrznie przerwałem mu w ten sposób modlitwę. Nie we wszystkich sprawach ludzie miejscowi byli jednak tak wrażliwi, gdyż np. picie alkoholu nigdzie nie było dla nich większym problemem, choć już nie publicznie na samym targu, jak dawniej, ale w pobliskich krzakach, trochę jakby w konspiracji. Podobnie traktowano chodzenie nocą na szarmuty (tj. do kobiet „lekkich obyczajów”), co uważano zazwyczaj za niewielkie przekroczenie 
zasad, które wywoływało jedynie sporo śmiechu, gdy się o tym wspominało między tutejszymi chłopakami.

Oczywiście, były też i abstrakcyjne rozmowy o zasadach, choć nie wchodzono raczej w głębszą „teologię". Dyskusję wywoływało zazwyczaj jakieś drobne wydarzenie, np. gdy odsunąłem od siebie garnek z wodą, z którego przed chwilą piła koza. Okazało się, że uczyniłem to niepotrzebnie, bo co innego by było, gdyby napił się z niego pies. Ten incydent rozbudził dyskusję na temat tego, jakie zwierzęta są "czyste”, a jakie nie są za takie uważane; co zanieczyszcza wodę, a co tego nie czyni. I tak, według moich gospodarzy, jeśli do wody wpadną małe owady, takie jak muchy, osy i skorpiony, to nadal pozostaje ona „czysta”, co nie zmienia faktu, że obecność w naczyniu tych ostatnich stworzeń może być niebezpieczna. Jeśli wodę pił osioł lub muł, to mamy do czynienia z sytuacją graniczną, ale parę odmówionych modlitw wystarczy, aby woda na powrót stała się „czysta”. To jeszcze jednak nic szczególnego, bo poważny problem zachodzi w przypadku, gdy trzeba w sposób rytualny oczyścić całą studnię; dyskusje na ten temat ciągnęły się aż do wieczornego wezwania na modlitwę.

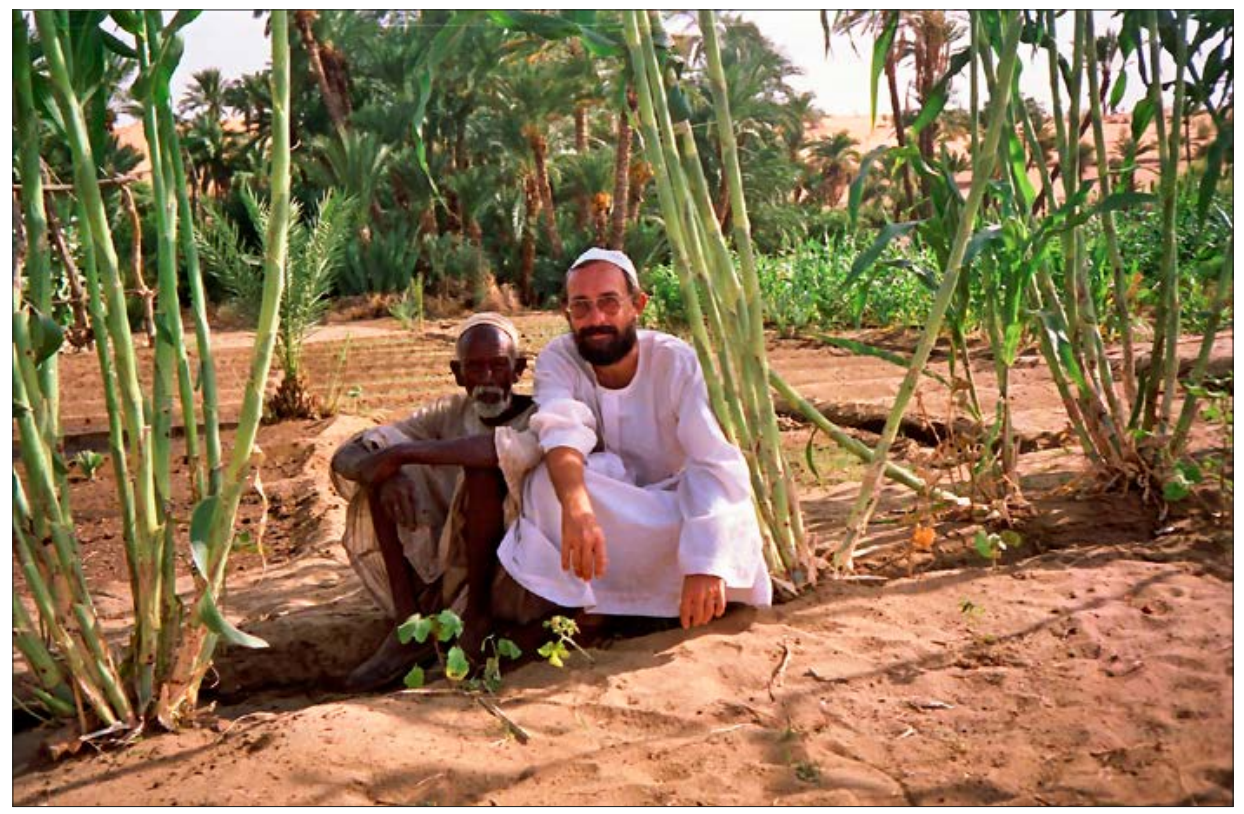

Fot. 6. W jednej z oaz Cheiranu.

Fot. M. Ząbek; zdjęcie wykonane przy pomocy osoby miejscowej

Do islamu starano się mnie przyciągnąć nie tyle krytykując dogmaty chrześcijańskie, czy zadając prowokacyjne pytania (w rodzaju: „Jak Bóg mógł mieć syna, skoro nie miał żony?"), co podając raczej pozytywne przykłady nawróceń różnych Chawadzi. Historie ich konwersji krążyły po całym Sudanie, dowodząc siły i „prawdy”, jaka jest nie tylko w islamie, ale przede wszystkim w "świętości" sudańskich awlija (przyjaciołach Boga). Opowiadano mi na przykład historię 
o Amerykaninie, który podczas snu usłyszał głos z Mekki Allahu Akbar! A gdy tam pojechał, wskazano mu wali („przyjaciela Boga” - człowieka świętego) ze wsi Zeriba należącej do plemienia Dżawazma w Kordofanie. Ów wali odmawiał z nim codziennie suplikacje, posługując się różańcem, dzięki czemu Amerykanin zapoznawał się z islamem i stał się pobożnym muzułmaninem do końca swego życia.

W moim przypadku nazyr zawiózł mnie do sławnego fakih (dosł. prawoznawcy) w Dar Hamid, imieniem Awad Asid, który zamieszkiwał niedaleko maleńkiej wioski Abre Gashia, między wsiami El Gaa a Koketi. Szejch mieszkał tam tylko z żoną i służącym, samotnie na pustkowiu, nie było zatem nawet gdzie uciec. Przebywałem u niego razem z nazyrem przez niemal tydzień. Siedzieliśmy i powtarzaliśmy godzinami poszczególne suplikacje koraniczne: Subhan Allah (chwała Bogu), Al-hamdulillah (Bogu niechaj będą dzięki), La illahail Allah (nie ma boga poza Bogiem), Allahu 'alam (Bóg wie najlepiej), Allahu akbar (Bóg jest wielki) i tak dalej, bez końca, aż do zupełnego zmęczenia, dbając o prawidłowy akcent i odpowiednio mocną intonację. Ani Szejch, ani nazyr nie tłumaczyli mi, po co to czynią i co zamierzają osiągnąć. Domyślałem się tylko, że pragnęli otworzyć moją niewierną duszę na ich „prawdę”. Ja jednak tylko obawiałem się, że znowu marnuję sporo czasu. Na szczęście, w chwilach odpoczynku od tych „ćwiczeń", dowiedziałem się o kilku interesujących rzeczach, jak np. o kryteriach prawa kisas (odwetu) i diya (odpłaty), czy też o tym, jak przygotowuje się „zasłony przed nieszczęściami”, czyli o muzułmańskich talizmanach, a także, jaką ofiarę trzeba złożyć wówczas, gdy Allah jest gniewny, jak miało to miejsce 9 lutego 1990 r., kiedy nastąpiło zaćmienie księżyca.

Trudnym czasem był dla mnie okres Ramadanu. Goszczący mnie nie przygotowywali w ciągu dnia żadnych posiłków. Sklepy, restauracyjki wiejskie, gdzie można było kupić gotowany bób z olejem i cebulą, także były zamknięte. Chcąc nie chcąc, musiałem pościć jak wszyscy, po kryjomu popijając tylko wodę.

Nawet poza Ramadanem jadano tu co najwyżej dwa niezbyt obfite posiłki, $\mathrm{w}$ tym aside (tę breje z prosa, nie wiedzieć czemu tłumaczoną jako porridge), której jedzenie nie bardzo mi odpowiadało, choć w końcu musiałem ją polubić. Zresztą posiłki we wsiach u zwykłych ludzi były często takie, że w Polsce nikt by tego nie chciał jeść, ale dobrze, jeśli w ogóle je przygotowywano. Próbowałem czasami pieczoną szarańczę i myszy polne, zdarzało się, że żułem żywicę z akacji, smakującą jak mdłe lekko kwaskowe cukierki, no i oczywiście, jako nikotynista, tombak (starty na proszek tytoń z sodą). Dużo lepiej było, gdy wypadał dzień targowy, wówczas jedzenie było lepsze i pojawiały się w ofercie warzywa. Nawet jak kupiłem sobie bób, nie zawsze miałem okazję zjeść go sam, gdyż niekiedy przysiadał się do mnie jakiś miskin (biedak) i bez pytania o pozwolenie wsadzał swą rękę do mojej miski. W krzakach, w ukryciu, można było się jednak napić z towarzystwem (trochę mniej wierzących) pożywnej merissy, a nocą czasami nawet ktoś przyniósł arage, tutejszy wysokoprocentowy bimber z daktyli.

Zazwyczaj jednak chodziłem tam głodny, czasami bardzo głodny, tak że zaczynałem rozumieć, jak głód może być bolesny - do tego stopnia, że aż chce się płakać. Nawet jednak, jak było źle, i to nie tylko mnie, bo miejscowym również, to nie wolno było narzekać. Wszystko musiało być zawsze dobre i wspaniałe! 
Pozytywne wzmocnienia w słowach, takich jak tamam, kwais, dżiddan, malesz, mafimuszkila (świetnie, dobrze, cudownie, nic takiego, nie ma problemu) powtarzane przy każdej okazji, były obowiązkowe, niezależnie od tego, czy było się zdrowym, czy się prawie umierało.

Lepsze jedzenie podawano tylko w wielkie święta, albo gdy organizowano zebrania starszyzny, czy w szczególnych sytuacjach, gdy mogłem być gościem u kogoś znacznego. Czasami wtedy zarżnięto barana, kurę, choć najczęściej tylko kościstą kozę - wówczas podawano jako przysmak niestrawione resztki z żołądka zwane abugazi.

$\mathrm{Z}$ drugiej strony, przebywając ciągle we wsiach i tak nie mogłem narzekać, bo gdybym, jak to sobie kiedyś wyobrażałem, przyłączył się do nomadów i wędrował z nimi wraz ze stadami, to nie wiem, czy bym taką eskapadę przeżył. Doświadczyłem tego tylko przez kilka dni, gdy nazyr zabrał mnie do jego „Arabów"4 wypasających owce. Różnica "cywilizacyjna" między ich obozowiskiem a miejscem, w którym znajdowały się kobiety, była ogromna. Przed skwarem $\mathrm{w}$ ciągu dnia nie było gdzie się schronić, w nocy zaś na świeżym powietrzu było często zbyt zimno. Posiłkiem była tylko dufana, rodzaj spalonego chleba pieczonego $w$ popiele, rozrobionego $z$ owczym mlekiem, pełnego zgrzytającego w zębach piasku, podawanego w nigdy nie mytej misce. Do picia była tylko ciepła i śmierdząca skórą woda z juków. Chodzenie za owcami w buszu też nie było tak romantyczne, jak mi się kiedyś wydawało.

Na szczęście przez większość czasu byłem zdrowy. Czasami miałem tylko kłopoty z żołądkiem, ale to dla Europejczyka w Afryce raczej sytuacja standardowa. W maju 1990 r. dopadła mnie prawdopodobnie malaria (nie wiem na pewno, bo nie miałem szans na zrobienie jakichkolwiek badań). Mając leki antymalaryczne, sam się wyleczyłem. Innym razem w czasie wielkiego upału przez miesiąc miałem na całej skórze swędzące potówki, ale to też było rzeczą normalną. Dopiero jak w lutym 1991 r. dopadła mnie żółtaczka, to opadłem z sił na cały miesiąc. Właściwie nie wiedziałem, co mi jest. Do El-Obejd przywiózł mnie z wioski Szerszar, położonej na północy Dar Hamid, swoim samochodem Jaakko Henttonen, przedstawiciel Międzynarodowej Organizacji Pracy (ILO), który akurat tamtędy przejeżdżał. Gdyby nie on, nie wiem, jakbym się stamtąd wydostał w tym stanie. W szkole prowadzonej przez Misjonarzy Kombonianów zorganizowano dla mnie kwarantannę i lekarza, zarządzono rygorystyczną dietę i po miesiącu w końcu stałem się trochę mniej żółty, i mogłem kolejny raz pojechać w teren.

\section{Kilka refleksji na zakończenie}

W Sudanie spędziłem, od października 1989 r. do końca marca 1991 r., prawie 18 miesięcy, z tego 4 razy, mniej więcej po 3 miesiące, przebywałem w Dar Hamid, a więc łącznie byłem tam prawie 48 tygodni. Pamiętam to bardzo dokładnie

\footnotetext{
${ }^{4}$ Tu słowo „Arabowie” odnosiło się nie do etniczności, tylko koczujących pasterzy.
} 
mimo upływu lat, gdyż odnotowywałem każdy miniony dzień niczym żołnierz, który odlicza czas, jaki pozostał mu do „rezerwy”. Dla mnie był to najdłuższy okres w moim życiu, tymczasem w Polsce niektórzy nawet nie zauważyli, że mnie nie było w tym czasie. Nie wtopiłem się w tubylczy świat, jak to sobie kiedyś planowałem, choć niewątpliwie w nim trochę uczestniczyłem i wiele z jego zasad zrozumiałem, i to na pewno bardziej niż niejedna z tych osób, które deklarowały w swych raportach, że prowadziły „obserwację uczestniczącą".

Na koniec pobytu byłem fizycznie wyczerpany, a do tego dochodziła stała niepewność, czy miejscowa służba bezpieczeństwa nadal będzie tolerować mój pobyt, gdyż coraz częściej stwarzano mi problemy. W Chartumie pechowo przechodziłem w pobliżu jednej z wielu antyrządowych demonstracji, które odbywały się w tym czasie. Security, która podczas kontroli odkryła przy mnie aparat fotograficzny, natychmiast mnie aresztowała. Na szczęście szybko wywołano film, na którym nie było zdjęć demonstracji i po ok. 12 godzinach zostałem wypuszczony z okropnie dusznej celi, w której nawet nie było łóżka.

Bilet powrotny kupiłem za ostatnie pieniądze, dzięki pośrednictwu Budimexu, w ciągle funkcjonującej na starych zasadach ambasadzie Związku Sowieckiego, dzięki czemu był on o połowę tańszy niż oferowany w biurze linii lotniczych.

Teraz wiem, że jeszcze dłuższy pobyt w terenie i tak nic by mi już nie dał nie miałem dostatecznie oryginalnego pomysłu, w jaki sposób zdobytą w terenie wiedzę należy „skonsumować” po przyjeździe, jak też wypróbowanego warsztatu opisu. Pojęcie „nauka” to niestety termin, który słabo pasuje zarówno do etnografii, jak i antropologii. Znacznie lepszym wydaje się pojęcie "sztuki”, które przecież także może prowadzić do odkrywania „prawdy” o tym świecie. Wymaga jednak, oprócz wiedzy, trochę talentu i treningu. To cała tajemnica udanej etnografii, a tym bardziej antropologii. Na końcu liczy się przede wszystkim sztuka pisania, chcąc nie chcąc, to ona jest ostateczną kwintesencją. Słabym pomysłem jest tylko jej porównywanie i ustawianie w rankingach z „nauką" w ściślejszym tego słowa znaczeniu.

Uprawiania etnografii w „prawdziwym terenie”, tj. realizowania badań tzw. intensywnych, długich, polegających na życiu sam na sam z tzw. tubylcami nadal bym jednak bronił, choć w swoim czasie jakże zazdrościłem tym antropologom, którzy mogli je prowadzić z bardziej bezpiecznej odległości. To zupełnie co innego niż jakiś ",teren zastępczy” czy tzw. „chodzenie na wywiady” lub etnografia „z doskoku”, z bezpiecznym refugium na zapleczu, do którego zawsze można się wycofać. Nie wystarczy gdzieś tylko być, aby wiedzieć, trzeba to jeszcze autentycznie przeżyć. Doświadczenie takie uczy pokory, nawiązywania rzeczywistych, bliskich relacji z ludźmi bardzo innymi, a jednak myślącymi zasadniczo bardzo podobnie. Takie doświadczenie jest lepszym sprawdzianem naszej postawy niż czcze deklaracje, że nie jesteśmy np. „rasistami”. Kto ma takie doświadczenie za sobą, ten nieco realistyczniej patrzy na świat, lepiej rozumie także to, co piszą i mówią inni, ma podejście krytyczne w stosunku do tzw. literatury przedmiotu i nasączonych nią ideologii. Ma w związku z tym jakąś szansę, aby zaistnieć w tej sztuce, jaką jest antropologia, choć nic tu nie jest z góry, dla nikogo, przesądzone. 
Sudan w latach 1989-1991 był na pewno dla mnie jakąś inicjacją, zmienił mnie. Niestety nie od razu wyciągnąłem $\mathrm{z}$ tego właściwe wnioski.

W swoim doktoracie (Arabowie z Dar Hamid. Społeczność w sytuacji zagrożenia ekologicznego) nawet nie myślałem o przedstawianiu dokładnej relacji z badań, napisaniu, jak się one naprawdę odbywały. Wtedy jeszcze nikt ode mnie tego nie oczekiwał. O czym tu w końcu było pisać, niektóre rzeczy wydawały się oczywiste, a o innych wstyd było wspominać. Dziś widzę, że nie do końca stanowisko takie było słuszne. Tym bardziej, że powtórzenie tego doświadczenia z różnych względów życiowych było już niemożliwe. Zachęcałbym młodych adeptów antropologii, aby podejmowali takie wyzwania, choć wiem, że nie jest to osiągalne dla wszystkich i nie jest wykonalne przy wielu tematach. Moich późniejszych studiów uchodźczych już w ten sposób nie mogłem prowadzić, a na to, by samemu zostać „uchodźcą”, nigdy się nie zdecydowałem. Mogłem tylko „wejść w skórę” tych, co się uchodźcami zajmują od strony instytucjonalnej i to uczyniłem. Taka droga także otwiera większe perspektywy poznawcze niż prowadzenie konwencjonalnych wywiadów. Niemal każda autoetnografia ma, moim zdaniem, przewage nad badaniami z „doskoku”, poprzez tylko wywiady i rozmowy.

Propozycję napisania tekstu do tomu jubileuszowego księdza profesora Wojciecha Bębna postanowiłem wykorzystać jako okazję do swego rodzaju antropologicznej „spowiedzi”, ku przestrodze, ale i ku przekonaniu wątpiących, aby uwierzyli, że ryzyko związane z takimi badaniami jednak się opłaca. Ponadto pragnąłem dać świadectwo, jak odmienne były nasze drogi do antropologii, doświadczenia terenowe i poglądy.

\section{Literatura}

Barley, N. (1997). Niewinny antropolog. Tłum. E.T. Szyler. Warszawa: Prószyński i S-ka.

Benitez, F. (1972). Indianie z Meksyku. Warszawa: PIW.

Clifford, J. (2006). Praktyki przestrzenne. Badania terenowe, podróże i praktyki dyscyplinujące w antropologii. W: M. Kempny, E. Nowicka (red.), Przekł. S. Sikora. Badanie kultury. Elementy teorii antropologicznej. Kontynuacje (s. 139-179). Warszawa: Wydawnictwo Naukowe PWN.

Kuper, A. (1999). Culture: the anthropologists' account. Cambridge: Harvard University Press. Lips, E. (1971). Księga Indian. Przekł K. Piesowicz. Warszawa: Wiedza Powszechna.

Malinowski, B. (1981a). Przekł. B. Olszewska-Dyonizial, S. Szynkiewicz. Argonauci Zachodniego Pacyfiku (s. 310). Warszawa: PWN.

Malinowski, B. (1981b). A.K. Paluch (red.). Przekł. A. Bydłon. Ogrody koralowe i ich magia. Warszawa: PWN.

Marcus, G.E. (1995). Ethnography in/of the World System: the Emergence of Multi-sited Ethnography. Annual Review of Anthropology, 24, 95-117.

[Pobłocki, K. (2018)] Pobłocki: Jak zostałem intelektualnym poliamorystą [wywiad przeprowadzony przez H. Walczyńskiego]. Kontakt, 4.06.2018, https://magazynkontakt.pl/ poblocki-jak-zostalem-intelektualnym-poliamorysta/ [dostęp, marzec 2020]. 
Vorbrich, R. (2020). Z zewnątrz i od wewnątrz. Przegląd sytuacji badawczych z perspektywy antropologicznej. W: M. Ząbek (red.), Przemiany kulturowe w Afryce. Historia i antropologia (s. 171-194). Warszawa: Wydawnictwa Uniwersytetu Warszawskiego.

Ząbek, M. (1998). Arabowie z Dar Hamid. Społeczność w sytuacji zagrożenia ekologicznego. Warszawa: Wydawnictwo Akademickie Dialog.

Film

[Sokolewicz, Z.] (2017). Jeden świat Zofii Sokolewicz, film dokumentalny, realizacja: M. Małanicz-Przybylska i P. Rożek;https://etnologia.uw.edu.pl/film-dokumentalny-o-prof-zofii-sokolewicz[dostęp, marzec 2020].

\section{SUMMARY}

Anthropological confession: Notes by an ethnographer from the Polish People's Republic on aspects of field research in Sudan

This article is based on field notes from the author's first independent ethnographic research, conducted in 1989-1991 in Sudan. Reflecting on the path that led him to anthropology during the last decade of the Polish People's Republic, just before the political transformation in Poland, he revisits his first ethnographic experience in the field, during student expeditions to Africa, focusing in particular on his long doctoral fieldwork in Sudan, spanning a year and a half. Examined years later, the text reveals facts, now salient but which then seemed obvious, or, for some reason, were not to be mentioned. The goal is to provide some insights into the history of Polish ethnography during the communist period.

Keywords: Africa, ethnography, Polish People's Republic, expeditions, field notes, Sudan 